Portland State University

PDXScholar

Summer 8-12-2016

\title{
A Study of the Intelligibility, Comprehensibility and Interpretability of Standard Marine Communication Phrases as Perceived by Chinese Mariners
}

Lillian Christine Holland

Portland State University

Follow this and additional works at: https://pdxscholar.library.pdx.edu/open_access_etds

Part of the Asian Studies Commons, English Language and Literature Commons, Language and Literacy Education Commons, and the Linguistics Commons Let us know how access to this document benefits you.

\section{Recommended Citation}

Holland, Lillian Christine, "A Study of the Intelligibility, Comprehensibility and Interpretability of Standard Marine Communication Phrases as Perceived by Chinese Mariners" (2016). Dissertations and Theses. Paper 3123.

https://doi.org/10.15760/etd.3119

This Thesis is brought to you for free and open access. It has been accepted for inclusion in Dissertations and Theses by an authorized administrator of PDXScholar. Please contact us if we can make this document more accessible: pdxscholar@pdx.edu. 
Thesis: A Study of the Intelligibility, Comprehensibility and Interpretability of Standard Marine Communication Phrases as Perceived by Chinese Mariners

by

Lillian Christine Holland

A thesis submitted in fulfillment of the requirements of the degree of

\author{
Master of Arts \\ in \\ Teaching English to Speakers of Other Languages
}

Thesis Committee:

Tucker Childs, Chair

Kimberley Brown

Lynn Santelmann

Portland State University

2016 
(C2016 Lillian Christine Holland 


\begin{abstract}
Worldwide, mariners use a variety of English as an International Language known Maritime English regardless of the first language spoken by the crew or port in which they enter. English knowledge and ability is therefore critical to a mariner's livelihood at sea and is also mandated by the International Maritime Organization. The ability to understand and be understood is paramount to safety at sea. This study investigated which accents of English a subset of Chinese mariners found easy or difficult to understand. The data from 39 Chinese mariners who listened to 8 Standard Marine Communications phrases was analyzed. The phrases were spoken in English by native speakers of Japanese, Russian, Chinese, and English. The participants provided verbatim responses followed by their assessment of the speakers' intelligibility and accent. Results indicated that participant position on board the vessel had a statistically significant effect on the intelligibility rating of the phrase heard and the overall understandability assessed of the speaker's accent. Moreover, participants reported that the phrases were deck commands. For deck officers who participated in the study, they phrases were easy to understand, for engineers, they were more difficult. These findings suggest that within the field of Martine English, further specification of English training is warranted and necessary to provide all mariners with authentic language relevant to their jobs. Initial Maritime English instruction at Maritime Education and Training (MET) institutions must include reading, writing, listening, and speaking which includes the spectrum of scenarios which all cadets may find themselves. Follow-on English classes for mariners
\end{abstract}


beyond the academies or maritime universities must necessarily be situated in the context of the mariner and be flexible enough to adjust to the needs of the mariners. Finally, assessment of the mariner's Maritime English language abilities must also strive to test authentic use of the language as indicated by the position. 


\section{Dedication}

To the men and women who sail the seas, who leave the comforts of family and home for extended periods of time and endure hardships and risk which none can fathom who have not lived it, this research is dedicated to you. May you have fair winds and following seas whereever you traverse the wild open oceans. 


\section{Acknowledgments}

This was an undertaking which could not have been accomplished without the expertise, patient and gentle nudging of more than a few. I am deeply grateful to my thesis committee (Dr. Tucker Childs, Dr. Kim Brown, Dr. Lynn Santelmann) for their hours spent encouraging, consoling, reading, and editing this text as well as to the other professors of the PSU Applied Linguistic Department who so willingly shared their knowledge and expertise. However, any errors herein are entirely my own. The dedicated professional English language instructors and experts of the International Maritime Lecturers Association and the International Maritime English were most kind and encouraging as they accepted me into their midst. I am also indebted to New Alliance Marine Training Center and the staff at SINOCREW as none of this would have been possible without their kind and gracious support finally, without the assistance of the PSU Nattinger scholarship, the travel necessary for the collection of data for this thesis would not have been feasible.

Of course, nothing is possible in my life without the support of family. I am eternally grateful for their love and encouragement during this somewhat trying endeavor. During our 3 hour commutes to Portland and home again, my sister graciously listened to my droning about all things linguistics and learned more than she likely wanted to about bilabial stops and vocal cord vibrations. My brother engineered and streamlined my methodology processes on the wall of mother's hospital room, patiently learned with me over the phone the statistics I needed, and continuously encouraged me in this undertaking. My mother instilled a solid foundation in learning, working and living from 
my earliest days. She too patiently listened to my linguistic ramblings for the past three years on our morning walks with the dogs (and cats). I am always indebted for their support. Lastly, I am very grateful to my husband, whose love for me and support for whatever crazy notion I have has never ceased in 20 years. 


\section{Contents}

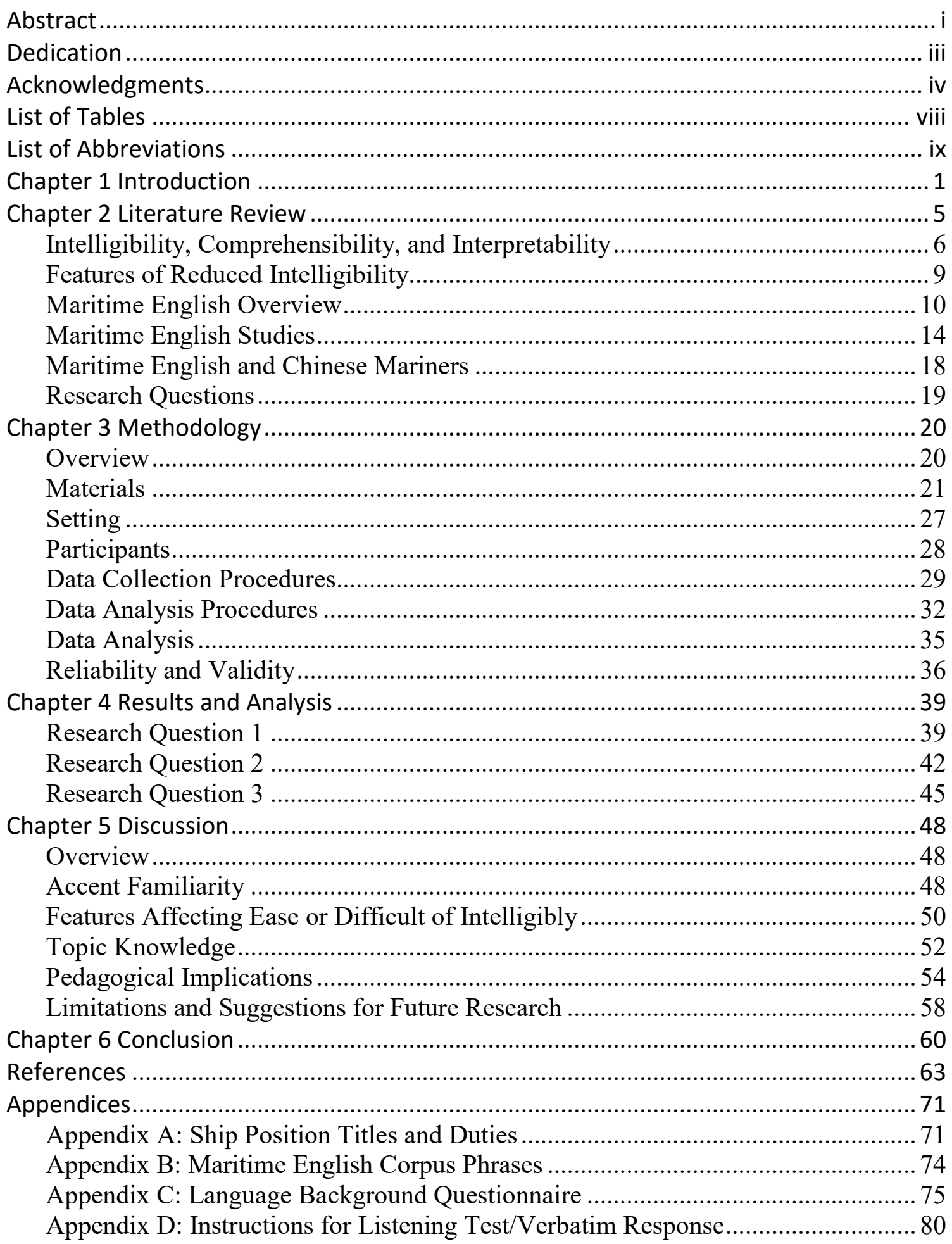


Appendix E: Instructions for Participant Impressions of Speaker............................ 81

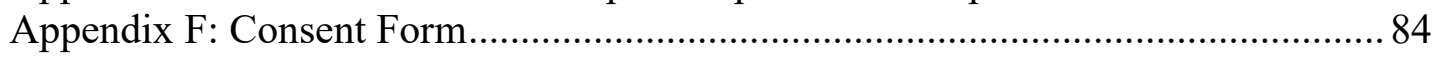

Appendix G: Participant Attitudes towards Nationality/L1 of Speakers................... 90

Appendix H: Areas of Reduced Intelligibility as Perceived by Participants ............. 91 


\section{List of Tables}

Table 1 Maritime Communication Phrases Used as Stimuli ....................................... 23

Table 2 Latin Square Design of Listening Tests..................................................... 25

Table 3 Intelligibility and Comprehensibility Ratings Mean Results ........................... 40

Table 4 L1 of Speaker Correctly Identified by Participant......................................... 41

Table 5 Post-hoc pair-wise comparisons of intelligibility rating by sentence ................ 43

Table 6 Intelligibility Rating by Speaker L1 …................................................. 44

Table 7 Variables and their significance on Intelligibility Ratings ............................. 46

Table 8 Areas of Difficulty/Ease for Participants by Sentence. .................................. 51 


\section{List of Abbreviations}

BRM - Bridge Resource Management - a course developed to enhance the team concept on board vessels and ensure adequate processes are in place to use all available resources during critical operations

$\mathrm{COC}$ - Certificate of Competency - a document issued by a recognized maritime authority which acts as proof of competency in a certain area of expertise ESP - English for Specific Purposes

GMDSS - Global Maritime Distress and Safety System - an international system which includes safety procedures, equipment and communication protocols aimed at increasing safety and making it easier to rescue vessels, ships and aircraft in distress.

IMO - International Maritime Organization - a specialized agency within the United Nations responsible for the safety and security of ships and the prevention of marine pollution.

L1 - First Language of an individual

L2 - Second Language of an individual

ME - Maritime English - an English for Specific Purposes' genre of English used by mariners throughout the world in order to communicate effectively their needs in the shipping industry.

MET - Maritime Education and Training - usually used in reference to vocation, university or private institutions who provide mariners with either initial or continued education

$\mathrm{M} / \mathrm{V}$ - Motor Vessel - a common title for a cargo ship. This abbreviation is used when naming a vessel in written form such as in the phrase "This is the $\mathrm{M} / \mathrm{V}$ (motor vessel) Maersk".

NNS - nonnative speaker; a speaker of English for whom the English language is not a native or mother tongue.

NS - native speaker; a speaker of English for whom the English language is a native or mother tongue

SMCP - Standard Marine Communication Phrases

SMNV - Standard Marine Navigation Vocabulary

STCW - Standards of Training, Certification and Watchkeeping for Mariners

TCPA - Time to closest point of approach

VTIS - Vessel Traffic Information System

VTS - Vessel Traffic Service - monitors confined and busy waterways and provides navigational advice to vessels in the area 


\section{Chapter 1 Introduction}

The shipping industry transports over $90 \%$ of the world's trade with an international fleet of merchant vessels and an international crew of 1.2 million mariners (IMO, 2012). Within this vast global network, English has been formally established as the lingua franca for both seaborne mariners and shore-based personnel as the mode of communication regardless of nationality, first language, or location. In recent years, increased attention has been paid to this language of the sea, known generally as "Maritime English", as most accidents at sea are attributed to the human element where English plays a critical role. The ability of mariners to effectively communicate with each other is vital for the preservation of crew, cargo, vessels, and for minimizing negative impacts on the environment:

Successful communication at sea is directly linked to clear and complete delivery and receipt of the target message between interlocutors. It can be said that the speaker's effective delivery of their intended message, and the listener's precise decoding and accurate understanding are the keys to successful maritime communications (Choi \& Park, 2015, p. 41).

Seafarers from non-native English-speaking countries constitute the majority of manpower in the maritime industry with approximately $50 \%$ of the officers and $51 \%$ of the ratings, (See Appendix A for a description of positions on board merchant vessels), employed from Asia and Eastern Europe (BIMCO, 2010). Due to the increase in mariners from these regions, particularly from China, the Philippines, and India, nonnative speakers (NNSs) are more likely to encounter other NNSs of English rather than 
native speakers (NSs) (BIMCO, 2010; Sampson \& Zhao, 2003; Trenkner \& Cole, 2010), and therefore, must be able to understand various accents of English.

Because of the increasing role that China and Chinese mariners play on the world's seas, this study evaluated the ability of Chinese mariners to understand different English accents. Their English proficiency level is frequently cited as a setback for their employment aboard the international fleet of merchant vessels. If international employment is obtained, integrating Chinese seaman with other nationalities on the same ship can be problematic. For this reason they are often employed as an entire crew rather than individually (Tang, Llangco \& Zhao, 2015). Few studies have examined spoken English between NNS-NNS and NS-NNS on the high seas, and few have examined the intelligibility of English by Chinese mariners. Therefore, an intelligibility study of Chinese mariners in the maritime domain is both warranted and needed.

To address this gap, I conducted an intelligibility, comprehensibility and interpretability study (hereafter referred to as an intelligibility study), in which 41 Chinese mariners listened to eight Standard Marine Communication Phrases (SMCP), ${ }^{1}$ (Appendix B), and provided feedback regarding the intelligibility of the speaker and their understanding of the phrase. These phrases were spoken in English by native speakers of Chinese, Russian, Japanese and English. Participants repeated the phrase verbatim as a

\footnotetext{
${ }^{1}$ Standard Marine Communication Phrases (SMCP) such as "My last port of call was New York" are English phrases used by mariners world-wide to standardize the communication at sea for navigation and safety. The SMCP are used during external communication such as ship to ship and ship to shore, and during internal ship communication such as during an emergency on board. The SMCP were adopted by the International Maritime Organization (IMO) in 2001 and are mandated for use per International Convention on Standards of Training, Certification and Watchkeeping for Mariners - 1978 (STCW) (IMO, 2002).
} 
measure of their intelligibility of the phrase, and answered questions regarding their perception of the speaker and their comprehension of the sentence. The verbatim response enabled me to determine which phrases or words were unintelligible to the participant and identify areas of reduced intelligibility (Zielinski, 2008). I analyzed areas of reduced intelligibility to determine what features of the unintelligible words contributed to comprehension difficulties. Finally, I analyzed the intelligibility and comprehensibility/accent rating of each phrase with respect to the participants' education level, years working in the marine industry, and position on board the vessel to determine the statistical significance of these variables on the participant ratings. The results indicated that the participant's position on board the vessel, either as a deck or engineer officer, had a statistically significant effect on their intelligibility and comprehensibility/accent ratings of the Standard Marine Communications Phrases to which they listened.

The motivation for this research stems from an adherence to the "intelligibility principle" (Levis, 2005, p. 370), a belief that effective communication is the goal of any language encounter and can be achieved regardless of one's accent. Effective communication can be explained as producing an utterance which is understood by the interlocutor and "is not solely speaker- or listener-centered, but is interactional between speaker and listener" (Smith \& Nelson, 2008, p. 429). The crux of any successful communicative event in the maritime domain is, therefore, the responsibility of both 
interlocutors: "Each carries the responsibility to be understood; each must make an effort to understand" (Berns, 2008, p. 329).

The remaining sections of this thesis are divided into chapters which include a literature review, methodology, results, and discussion of the data. Chapter 2 of this thesis discusses the relevant literature which exists regarding intelligibility studies and provides an overview of Maritime English (ME). The literature review demonstrates the need for an intelligibility study of ME as part of the general domain of English for Specific Purposes. In Chapter 3, I describe my methodology for conducting the study, followed by the results (Chapter 4) and a discussion of the findings (Chapter 5). Many terms specific to the maritime industry with which the reader may be unfamiliar will be used throughout this thesis. A list of abbreviations is provided on page xi. An explanation of the various positions on board merchant vessels with their duties is provided in Appendix A. 


\section{Chapter 2 Literature Review}

This chapter establishes the need for an intelligibility study within the maritime industry. I review intelligibility studies and provide an introduction to Maritime English (ME) and the current research on this variety of English.

The first section defines the constructs intelligibility, comprehensibility, and interpretability and explores applicable intelligibility studies (Smith, 1987; Smith \& Rafiqzad, 1979; Zielinksi, 2008). These three constructs have been at the center of discussion regarding how to evaluate the listener's ability to understand or the speaker's ability to be understood, (for overviews see Berns, 2008; Jenkins, 2000; Munro \& Derwing, 2011; Nelson, 2008; Pickering, 2006; Smith \& Nelson, 1985). That discussion has led to pedagogy abandoning instruction in English pronunciation due to the controversy over 'whose pronunciation is correct' and 'who judges what is correct' (Derwing \& Munro, 2005; Jenkins, 1998; Levis 2005). However, the issue of being understood is still relevant, and arguably is the key to any communicative event and thus worthy of study.

There is some consensus that "understanding" can be broken into three distinct components, namely: intelligibility, comprehensibility, and interpretability. For the purposes of this study, I will define them as follows:

Intelligibility: word/utterance recognition;

Comprehensibility: word/utterance meaning (locutionary force) 
Interpretability: meaning behind word/utterance (illocutionary force)

(Smith \& Nelson, 1985, p. 334)

The second section defines Maritime English (ME), specifically with respect to the Standard Marine Communication Phrases (SMCP), as a product of the international conventions which were adopted as a means of codifying English for use in the maritime environment for mariners with varying first languages. The last section reviews the current literature pertaining to ME. Many studies in this genre of ESP address instructor competence within the field of ME; few, however, address issues of intelligibility, comprehensibility and interpretability, particularly with respect to Chinese mariners. Because Maritime English is used in the realm of a lingua franca, it is critical that interlocutors with various first languages (L1s) be able to understand each other. As Chinse mariners increase their numbers in the global mariner workforce, the ability for them to understand other accents of English and be understood is equally critical.

\section{Intelligibility, Comprehensibility, and Interpretability}

This study was designed to measure an aspect of each of these components; however the totality of 'understandable speech' is not quite as simple as these three definitions and involves other social and linguistic factors such as accent and identity (Levis, 2005). Social and linguistic factors play a role in each of the interlocutors' willingness to participate in the exchange and to understand or be understood. As the composition of crews changed from a single nationality and language aboard to an 
increase in multi-lingual, multi-cultural, and multi-ethnic crews, additional communication training, such as Bridge Resource Management (BRM) training, has evolved in an effort to promote and enhance communication between all members of a ship's bridge team. Because of this multi-lingual and multi-cultural environment on board, as well as within the port systems, the need for intelligible and comprehensible English has become vital for the safety and security of the crew, vessel and cargo. Participants' attitudes and experience with multi-national and multi-ethnic crews was beyond the scope of my thesis, yet remains an important factor when assessing intelligibility and comprehensibility and is a worthwhile subject for future study.

One of the first comprehensive intelligibility studies which addressed whether native speaker English was more intelligible than other varieties of English was conducted by Smith and Rafiqzad (1979). Their study compared the degree of intelligibility of spoken English by nine educated NS and NNS from 9 countries (Hong Kong, India, Japan, Korea, Malaysia, Nepal, the Philippines, Sri Lanka, and the United States) as assessed by 1386 participants from 11 different countries (Bangladesh, China, Hong Kong, India, Indonesia, Japan, Korea, Malaysia, Nepal, the Philippines, and Thailand). In a cloze test, participants wrote in missing words from a recorded text and then completed a Listening Comprehension Questionnaire. The findings indicated that the NS (Standard American Variety) and the Hong Kong speaker were always ranked among the bottom three in intelligibility, while the Japanese speaker was always among the top five speakers. The study also addressed the issue of comprehensibility by asking 
participants to estimate their overall comprehension of the samples they listened to. The findings showed that the rank order of 'understanding' or comprehensibility and intelligibility listed the same top four nationalities of speakers: India, Sri Lanka, Malaysia, and Japan (in differing orders), as most intelligible and comprehensible; and listed the US and Hong Kong speakers among the least intelligible and least comprehensible. Following this study, I will use stimuli from three NNS varieties (two speakers of Japanese, Chinese, and Russian) and two NS (US and Canadian) to assess these speakers' intelligibility and comprehensibility of spoken Maritime English as perceived by Chinese mariners.

Smith (1987) also tested the effect of participants' proficiency in English, topic familiarity, and familiarity with accents with their perception of the speaker's intelligibility, comprehensibility and interpretability. While listening to a recorded conversation between two NNS, participants were given a cloze test to fill in (assessing intelligibility). Following the conversation, three multiple choice-questions were asked about the content (assessing comprehensibility), and participants were asked to paraphrase three phrases (assessing interpretability). Smith's findings suggested that the speakers from Japan, India and US were most intelligible and participants who were familiar with a variety of accents of English did better on the test of interpretability. Familiarity with topic and speech variety also had an effect on how well the participants understood the conversation. Other studies of NNS speech intelligibility and the impact of familiarity with topic and accent have been conducted with mixed findings (Bent \& 
Bradlow, 2003; Matsuura, Chiba, \& Ara, 2012; Tauroza \& Luk, 1997). Bent \& Bradlow, (2003) found that in addition to a matched interlanguage intelligibility benefit - a benefit of intelligibility for participants who shared an L1 with the speaker - a 'mismatched' intelligibility benefit existed. A mismatched intelligibility benefit existed when an NNS listener who's L1 did not match the speaker, rated the intelligibility of NNS higher than NS in the study. Bent and Bradlow findings suggest that native accents of English are not always the most intelligible or comprehensible for NNSs.

\section{Features of Reduced Intelligibility}

To determine what features contributed to intelligible speech, Zielinski (2008) analyzed the areas of reduced intelligibility in the connected speech of three NNS as identified by three NS listeners. This exploratory study found that the NS listeners relied heavily on stress to identify words, and were misled by misplaced stress and non-standard production of segments. One finding of the study was that when three of her listeners used native speech processing strategies to understand NNS speech, they found the speech less intelligible. Zielinski acknowledged that listeners from first languages other than English may allow different features in the speech other than stress to affect intelligibility. While stress may be important for NS to understand NNS speech, stress may have no impact on NNS intelligibility of NNS speech.

Jenkins $(1998,2000,2004)$ had earlier established that same interpretation of NNS - NNS interaction suggesting that "the phonological and phonetic factors involved 
are not necessarily the same as those involved in communication between a native and nonnative speaker of the language" (2004, p 115). In her earlier work Jenkins (1998, 2000) highlighted several features of spoken English contributing to intelligibility between NNSs; stress and certain segmentals were essential for intelligibility. However, she noted that "little research has been conducted into the intelligibility of English among its non-native speakers from different L1s" (Jenkins, 1998, p. 121).

Other researchers have studied intelligibility and the role of phonological features (Field, 2005), yet few studies have examined NNS English intelligibility from the perspective of Chinese speakers. Zhang (2013), however, examined the phonological features that hampered intelligibility of Chinese-accented English. Her study included the speech of 32 speakers from 7 Chinese languages, and 32 listeners from 19 different nationalities, although she did not use Chinese L1 listeners. Her findings suggest that vowel quality and the addition of vowels after word endings hampered the intelligibility of Chinese NNS English speech. As these studies show, more research on the features affecting intelligibility for NNS is needed. My study of NNSs in a real-world setting addresses this gap.

\section{Maritime English Overview}

The use of English by seafarers can be traced back to the time of British rule when the shore language in various ports was English, and mariners with different L1s would need to conduct their ships' affairs in English (Cole \& Trenkner, 2012). Yet the 
international community did not agree on an 'official' language of the sea until 1977. In that year English as the lingua franca in the maritime domain was codified by the International Maritime Organization (IMO) in adopting the Standard Marine Navigational Vocabulary (SMNV) for the purpose of improving navigation in ports around the world (IMO, 1978). In addition, IMO adopted the International Convention on Standards of Training, Certification and Watchkeeping for Mariners - 1978 (STCW) thereby standardizing levels of competency for crew members. Countries signatory to the IMO issued mariner certificates of competency (COCs) certifying that the standards of education and knowledge pursuant to the STCW had been met by the mariners. Included in this certification was an implied competency in English which each country interpreted (sometimes quite differently), allowing for the safe operation and navigation of merchant vessels in ports worldwide.

While the STCW codified standards for English proficiency levels for various ranks on board a vessel, and the SMNV provided a list of agreed-upon vocabulary, the practical implementation of achieving the standards of competency was not without difficulties. Levels of linguistic proficiency, for example, varied widely among mariners (Bakr, 1979; Trenkner, 2005). Initially, this subset of words and phrases was used for ship-to-shore and ship-to-ship communication via Very High Frequency (VHF) radio transmission in the navigation of the vessel. A specialized variety of English pertaining specifically to the maritime domain included archaic words, collocations, and word meanings not in use in any other specialized field. For instance, eight 'message 
markers' established the intent of a phrase. One such message marker, "instruction", followed by a specific maneuvering command alerted the recipient to a message that was not advice, a suggestion or a warning, but rather information that needed to be acted on. To request confirmation that the interlocutor could hear the message, rather than ask the question, "Can you hear me?" or "Can you understand me?" A mariner would ask, "How do you read?" His interlocutor might answer "I read you one", indicating the transmission was barely perceptible. More archaic nautical vocabulary with specific nautical meanings such as "cables" (1/10 th of a mile), "forecastle", "aft", and "beam" remained a standard part of any mariner's vocabulary.

Despite the IMO adoption of the SMNV in 1977, which addressed the specific communication contexts of navigation in which mariners should use English, these formulaic expressions were not widely adopted. The lack of an agreed upon assessment measure resulted in member states creating their own standards, particularly with regard to language competency. Continued maritime accidents with communication breakdowns as a contributing factor resulted in high death tolls. This fact put in motion the revision of the SMNV and its eventual replacement with the more comprehensive SMCP (Trenkner, 2005; Cole \& Trenkner, 2012).

From the adoption of the SMNV in 1977 until 2001, the maritime industry had changed considerably (Couper, 2000). Several factors were considered in the revision of the SMNV. One change which significantly affected the revision was the makeup of the crew: more and more crews consisted of multi-lingual and multi-ethnic mariners; clearly 
a common language for on-board communication was needed. Additionally, a tremendous increase in the number of ships worldwide carrying high-value cargo and large numbers of passengers created increasingly congested traffic areas leading into and out of ports. There also existed a need for standardized safety as well as navigation phrases (Trenkner, 2005). In 2001, the IMO adopted the SMCP, which replaced the SMNV. The former was designed to address shortcomings in the latter, particularly in safety-related verbal communication between crews and passengers, which had not been previously addressed:

The SMCP builds on the basic knowledge of the English language. It was drafted on purpose in a simplified version of Maritime English to reduce grammatical, lexical, and idiomatic varieties to a tolerable minimum, using standardized structures for the sake of its functional aspects, i.e. diminishing misunderstanding in safety related verbal communication, thereby endeavoring to reflect present Maritime English language usage on board vessels and in ship-to-shore/ship-to-ship communications. (IMO, 2002, p. 10).

These phrases were designed to enhance communication during emergency situations and during navigation so that, in spite of noise, distance, accents, and stress, communication could occur that was clear, concise, and unambiguous. However, despite the expansion of communication phrases to over 3000 distinct phrases covering external communication and onboard safety, accidents continued with communication breakdowns frequently cited as a contributing factor (Cole \& Trenkner, 2008; Demydenko, 2010; Johnson, 1999; Ziarati, R., Ziarati, M. and Çalbaş, 2009). To address the issue, in June 2010 the IMO amended the STCW in what is known as the Manila Amendments (IMO, 2010); as a 
result, new standards in crew competency were created including mandating the use of English by crew members.

Because the maritime environment is dominated by non-native speakers (NNS) of English (Sampson \& Zhao, 2003; Trenkner \& Cole, 2010), the majority of communication in English occurs between NNS either on board the vessel or with NNS on shore. Research has shown, however, that a gap exists between the mandated language included in the SMCP and the actual language used by mariners. Sampson \& Zhao (2003) documented very little use of the SMCPs during their time aboard vessels. During the course of her discourse analysis of VHF transmissions, Dževerdanović-Pejovic (2013) found the application of SMCP questionable as a gap existed between the prescribed use of SMCP and use of language by mariners (p. 377-378). This finding provides a wealth of possible study areas in applied linguistics, including further study of this specialized means of communication (Cole \& Trenkner, 2012). This study addresses the assessment of intelligibility by NNS mariners of SMCP spoken by NNS and NS, thereby adding to the research on which future pedagogy can be based.

\section{Maritime English Studies}

As discussed in the last section, it is of great importance for the safety and security of the crew, the vessel, and the cargo, that mariners speak English in a way intelligible to all with whom they interact. Yet, despite the dominance of NNSs of English working in the maritime industry throughout the world, little research addresses 
the issue of intelligibility within this population. Franceschi (2014) noted that most research in Maritime English was focused mainly on language pedagogy (Cole, Pritchard, \& Trenkner, 2007; Demydenko, 2012; Dirgayasa, 2014).

Although a few studies have examined written and spoken communication, most Maritime English studies have focused on language pedagogy, as mentioned above. A recent study analyzed the radio transcripts between the Motor Vessel (M/V) Maersk Kendal and the Vessel Traffic Information Service (VTIS) prior to the grounding of the M/V Maersk Kendal in the Singapore Strait on 16 November $2009^{2}$ (DževerdanovićPejovic (2013). The analysis revealed several deviations from SMCP, which contributed to unclear communication. For example, in an attempt to communicate the location of a vessel to the M/V Maersk Kendal, the VTIS operator said, "She is not leaving Singapore, she is not leaving Singapore" to which the M/V Maersk Kendal replied, "Got the name of the tanker - Samho Jewelry. Thank you." The VTIS replied to the statement with "It appears that you are heading towards her, over". This exchange is an example of a clearly intelligible and comprehensible exchange of information; however, the correct interpretation of the VTIS utterance (interpretability) was not realized by the M/V Maersk Kendal. Follow-up statements by the VTIS to the M/V Maersk Kendal indicated that the M/V Maersk Kendal was on a course to collide with the M/V Samho Jewelry and to avoid doing so, the M/V Maersk Kendal altered her course and ran aground. This example illustrates the complexity of using the SMCP in real-world

\footnotetext{
${ }^{2}$ For a detailed investigation and analysis of the M/V Maersk Kendal grounding, see Maritime Accident Investigation Branch Report, (MAIB) Accident Investigation Report 2/2010.
} 
situations. Despite clearly intelligible and comprehensible utterances, the meaning (locutionary force) and intent (illocutionary force) of those utterances was not perceived by the listener (M/V Maersk Kendal). Additional Maritime English studies of this nature are necessary to identify the elements impeding communication.

The use of SMCP by the Vessel Traffic Service (VTS) in Mumbai, India, has also been studied (Kataria, 2011). Findings indicated that VTS and ship operators' radio transmissions used 'normal' English rather than SMCP. For example, one exchange between the VTS and the M/V Mikhail included non-standard interaction: Mikhail - good afternoon Sir VTS - yeah Mikhail note down the position ... keep safe distance from other vessels within that area you can drop anchor (p. 31) The latter phrase, "yeah Mikhail note down the position ... keep safe distance from other vessels within that area you can drop anchor" is informal and unclear regarding what the VTS is trying to communicate. The meaning of the VTS statement cannot be derived without further clarification requests. The study concludes by suggesting that Maritime English is "normal English interspersed with nautical terms":

The VTS operators speak slowly, repeat, use phonetics ${ }^{3}$, use closed loop communication ${ }^{4}$ and use brief standard phrases/sentences especially useful when they encounter challenges in communication with vessels with foreign crew, mostly from Europe, China and Southeast Asia. This helps streamline ship-to-shore VHF communication and serves to maintain clarity and dispel confusion. (Kataria, 2011, p. 32)

\footnotetext{
${ }^{3}$ In this sense, phonetics refers to spelling words using the International Radiotelephony Spelling Alphabet.

${ }^{4}$ Closed-loop communication is a communication technique where the receiver of the message reaffirms what the speaker said. By doing this, the originator of the message can confirm whether the intended message sent was the message received by the listener.
} 
This example illustrates that clarity in communication does not lie solely in an intelligible statement. Further analysis would be necessary to determine if the M/V Mikhail actually understood the intended message of the VTS operator.

One study has assessed the intelligibility of NS and NNS using Maritime English. Shore-based Japanese VTS workers were asked their perceptions of NS and NNS of English with whom they came in contact (Uchida and Takagi, 2012). The Japanese VTS operators were asked to identify the nationalities of speakers who were hardest to understand and identify what made them so hard to understand. The VTS operators identified Russian, Ukrainian, and Chinese NNS of English, as well as U.S. and British native speakers, as the most difficult to understand. The reasons for their difficulties were identified as "heavy accent" for the first three, and "rapid speech" for the latter. While Uchida and Takagi's study identified which NNSs were difficult for Japanese VTS operators to understand, their study did not examine what language features constituted a heavy accent. Additionally, their study reported native US and British speakers as having rapid speech, yet no measures of speaking rate were provided. What is missing, then, is an empirical analysis of the misunderstood speech. For instance, was the difficulty in intelligibility due to slurred connected speech, ${ }^{5}$ or were US and British speakers using words not a part of the Japanese VTS speakers' lexicon? This study will address such questions from the perspective of the Chinese mariner.

\footnotetext{
${ }^{5}$ Technically speaking, speakers not reaching articulatory targets.
} 


\section{Maritime English and Chinese Mariners}

The numbers of Chinese mariners working on foreign vessels has grown significantly during the previous two decades from 20,000 in the 1990 's to approximately 120,000 in 2014 (Tang, Llangco \& Zhao, 2015). In the mid-1990's, China was predicted to become one of the top suppliers of maritime workers; the number of Chinese mariners currently working in the international maritime industry makes Chinese mariners the second largest international seafaring labor pool, second only to Filipino mariners. However, English proficiency remains a challenge for Chinese seafarers and the use of SMCP is limited (Gang, 2008; Tang et al., 2015).

While it is widely acknowledged that in order to safely navigate and operate vessels in international waters mariners must be able to communicate essential information clearly, concisely, and unambiguously to other mariners, how one achieves clear, concise and unambiguous communication is a moveable target. This study focuses on the listener and their understanding of a set of standard phrases. The goal is to identify the phonetic factors contributing to what is perceived as unclear and ambiguous speech by Chinese listeners and what other factors may bear on understanding. Leading researchers in the fields of intelligibility, comprehensibility and pronunciation continue to call for replications and additional studies focused on NNSNNS interaction (Jenkins, 1998; Munro \& Derwing, 2015). Additionally, leading professional linguists and Maritime English instructors continue to call for empirical 
research in this field of applied linguistics. This study will attempt to answer at least some of these calls, as detailed below.

\section{Research Questions}

My research will address the following questions:

1. For Chinese mariners, which accents of English are easiest or most difficult to understand when listening to Standard Marine Communications Phrases and why? How do the participants characterize their ease or difficulty in understanding?

2. What features of the stimuli made the speech easy or difficult for the Chinese mariner?

3. Does education level, experience in the maritime industry, position on board affect the Chinese mariner's ability to understand NNS of English?

By answering these questions, I will add to understanding intelligibility in Maritime English. The research could suggest teaching strategies, e.g., a focus on explicit pronunciation techniques or communication strategies for listeners who encounter an unintelligible speaker as well as highlight the need for authentic language used for instruction. 


\section{Chapter 3 Methodology}

\section{Overview}

\section{Introduction}

I wanted to explore the intelligibility, comprehensibility and interpretability of SMCP phrases as understood by Chinese Mariners both quantitatively and qualitatively. I chose a mixed-method approach as it allowed me to collect verbatim responses from mariners working in the industry and measure the participant's initial understanding of the phrase (Munro, 2008). Furthermore, this approach provided the context to explore, through open-ended questions and participants' ratings, how participants perceived the accent. It provided opportunity for them to explain to me what about the phrases they did or did not understand. Collection methods used included a "Language Background Questionnaire" (Appendix C), which included questions about their language use and job or position on board the vessel. Participants' responded to hearing eight SMCP phrases with an oral restatement of what they heard (Appendix D). This session was followed by a discussion of what the phrase meant as well as the participants' ratings of their understanding of the speaker and of the speaker's accent (Appendix E). Additionally, I assessed the participants' understanding based on their repetition of the phrase.

The following sections describe the materials I created, the context of the study, the participants, and the procedures I used for collection and analysis. 


\section{Materials}

Language Background Questionnaire (LBQ). Using the Language Background Questionnaire (Appendix C), I requested that the participants provide background on their language use as well as the context in which they used English. This questionnaire was translated into Mandarin and was presented in paper format in both English and Chinese. The LBQ requested the following information of participants:

Biographical/Language Data

Nationality

Age

First language(s),

Other languages spoken,

First language of father and mother,

Education level,

Number of years studying English

Language Use in Job Setting

How often they spoke English,

Their current position or job on a ship,

Number of years working in the maritime industry,

To which countries they sailed,

With which other nationalities they worked, and

Contexts of language use on board vessels. 
The quantitative data from the LBQ allowed me to evaluate the factors which significantly affected the participants' ability to understand the various accents of English. The data was used to characterize participants with respect to their language training and use, as well as their overall education and experience in the maritime industry. These data were analyzed for the potential effects of significance on the participant's ratings of intelligibility and comprehensibility of the stimuli.

Stimuli. The stimuli used for the listening tests were extracted from the Maritime English Corpus ${ }^{6}$, an audio recorded collection of seven sets of maritime messages (Takagi \& Stone, 2010; see Appendix B). Each of the seven sets of messages contains one or more sentences using Standard Marine Communication Phrases (SMCP). Fiftytwo mariners with 28 language backgrounds recorded the messages resulting in 1456 recorded sets of messages. No biographical information regarding the speakers is known other than their nationality (which is presumed to be their first language as well). The speakers recorded each of the seven sets of messages in .wav format (MONO, 16 bit resolution, $11 \mathrm{~K})$.

From these seven sets of messages, I selected eight phrases for the study (Table 1, p. 23). These eight phrases extracted from the corpus recordings were chosen due to the familiarity that participants would have with the lexis, semantics and grammar. Because all my participants were mariners, I expected that in accordance with the STCW requirements for English language use on board vessels, they would have adequate

\footnotetext{
${ }^{6}$ The corpus was compiled by Dr. Takagi and can be found at: http://www2.kaiyodai.ac.jp/ takagi/pweb/wme.htm.
} 
general Maritime English language knowledge to understand the phrases. My participants would be able to understand the phrases because of their vocational or university studies of Maritime English as well as their experience on board vessels.

During the pilot study, I replaced one phrase because it was a fragment. The phrases were selected to control for word length as the participants were asked to restate what was said as a measure of intelligibility. Each of the eight phrases contained between 5-8 words and between 7-13 syllables. Studies have indicated that generally speaking, participants can remember or recall between 6-8 'chunks' of information (Miller, 1956). Table 1 Maritime Communication Phrases Used as Stimuli

\begin{tabular}{|c|l|c|c|}
\hline No & \multicolumn{1}{|c|}{ Sentence } & $\begin{array}{c}\text { Word } \\
\text { Length }\end{array}$ & Syllables \\
\hline 1 & $\begin{array}{l}\text { My last port of call was PLACE NAME. (Place name varied based } \\
\text { on L1 of Speaker: Chinese 1 - Dalian, Japanese 1- Osaka, Russian 1- } \\
\text { St. Petersburg, English (U.S) L1 - Castine) }\end{array}$ & $7-8$ & $7-10$ \\
\hline 2 & Make fast the tug on the starboard quarter. & 8 & 10 \\
\hline 3 & Rig the pilot ladder one meter above water. & 8 & 13 \\
\hline 4 & My present course is one three five (135) degrees. & 6 & 8 \\
\hline 5 & We will use the starboard anchor. & 5 & 8 \\
\hline 6 & The pilot boat is approaching. & 6 & 9 \\
\hline 7 & Put seven shackles in the water. & 8 & 10 \\
\hline 8 & $\begin{array}{l}\text { The TCPA is thirteen (13) minutes. } \\
\text { (each letter of “TCPA" (Time to Closest Point of Approach), is said as }\end{array}$ & & 10 \\
\hline
\end{tabular}

Speakers of Stimuli. I selected eight male speakers out of the 52 speakers available, with L1s of Chinese, Russian, Japanese, and English. Two speakers from each 
L1 were selected to average out the effects of variability between the speakers (Gooskens, 2013). All speakers were male to control for gender. Russian speakers were selected because of a study which found that Russian and Chinese NNS were the most difficult to understand for Japanese maritime industry workers (Uchida \& Takagi, 2012). I wanted to determine whether Chinese NNS experienced misunderstandings in the same way. Additionally, Chinese speakers were selected to determine the influence of accent familiarity or "matched interlanguage speech intelligibility benefit" (Bent \& Bradlow, 2003, p.1606). The concept of "matched interlanguage speech intelligibility benefit" suggests that NNS who share a common L1have similar speech production and perception in the target language, Due to the influence of the shared phonetic and phonological knowledge of the L1, a listener from the same language background as the speaker will find the speaker to be more intelligible than NS or other NNS who do not share their L1, (p. 1607). The native speakers were selected as a baseline for a ‘standard’ English dialect (Zampini, 2008).

Listening Test Design. One measure of intelligibility is achieved by asking participants to repeat verbatim what they hear. For this study, I created four listening tests and asked the participants to repeat what they had heard. Table 2 illustrates how the tests were designed. The four listening tests were comprised of the eight phrases spoken by one of the 8 speakers using a total of 32 unique phrases. Each of the eight phrases was spoken by one person from each L1 in each of the four tests ensuring that among the four tests, each phrase was spoken by a speaker from a different L1 background, a modified 
Latin square design (Gooskens, 2013). The sentences were presented in the same order for each test. Having participants listen to only one of the four tests mitigated concerns of speaker familiarity with the eight sentences yet allowed listeners to hear two speakers from the same L1 background. This design is similar to that of Becker and Kluge (2014) who tested the intelligibility of English as perceived by Brazilian Portuguese speakers by creating a test of words spoken by eight speakers from four L1s (American English, Mandarin, German, and Japanese).

Table 2 Latin Square Design of Listening Tests

\begin{tabular}{|l|l|l|l|l|}
\hline Sentence & Test 1 (L1) & Test 2 $(\mathbf{L 1})$ & Test 3 $(\mathbf{L 1})$ & Test 4 (L1) \\
\hline Sentence 1 & Chinese 1 & US & Japanese 1 & Russian 1 \\
\hline Sentence 2 & Chinese 2 & Canadian & Japanese 2 & Russian 2 \\
\hline Sentence 3 & Russian 1 & Chinese 1 & US & Japanese 1 \\
\hline Sentence 4 & Russian 2 & Chinese 2 & Canadian & Japanese 2 \\
\hline Sentence 5 & Japanese 1 & Russian 1 & Chinese 1 & US \\
\hline Sentence 6 & Japanese 2 & Russian 2 & Chinese 2 & Canadian \\
\hline Sentence 7 & US & Japanese 1 & Russian 1 & Chinese 1 \\
\hline Sentence 8 & Canadian & Japanese 2 & Russian 2 & Chinese 2 \\
\hline
\end{tabular}

This table depicts how the four listening tests were designed and includes which sentences were spoken by which L1 speaker. Among the four tests, each sentence was spoken once by a speaker from the four represented L1s. See Table 1 (p. 23) for the full sentences.

Questions to Elicit Participant Impressions of Speaker. In response to the phrases that the participants heard, I designed a series of questions to elicit the participants' impressions of the speaker (Appendix E). These questions were designed to assess the participants comprehensibility and interpretability of the statement.

Comprehensibility was assessed through questions about how easy or difficult the stimuli 
were to understand, and interpretability was assessed by asking the listeners what they would do or say in response to the stimuli and by or having them explain the meaning of the phrase. The answers to these questions showed which speakers were considered intelligible, comprehensible, and whether subjects understood the intent of the utterance (interpretability). The open-ended nature of the questions provided an opportunity for participants to provide details about their understanding. By using a mixed-methods approach in my research design, I increased the reliability and validity of my data by obtaining not only the quantitative assessment of intelligibility and comprehensibility/ accent ratings, but a qualitative assessment of intelligibility by the participants explaining their answers.

The first question, for example, "If you were on a ship, what would you do or say in reply if you heard this phrase?", aimed at eliciting whether the participant understood the illocutionary force behind the phrase. I also allowed participants to explain what the phrase meant, as this seemed an easier task for them to understand and produced the same results. Subjects were then asked to assess how well they understood the words in each of the phrases using a 5-point scale. As a measure of comprehensibility/accent, participants rated how difficult they thought the speaker's accent was to understand using another 5-point scale (Munro \& Derwing, 1995). Open-ended questions such as "What made the accent easy or difficult to understand?", and "What words were difficult to understand?" were asked to obtain the participants' evaluation of the speaker's production and to identify particular segments of the phrases that were problematic. To 
determine the listener's familiarity with the accent, I asked the participant to identify the L1 of the speaker and to state whether they had heard or interacted with anyone speaking the language.

\section{Setting}

The settings for the collection were two training centers for mariners in China, both in large urban areas. The locations in China were selected because a Chinese colleague extended an invitation to interview mariners taking continuing education classes at these training centers. This allowed me to have access to non-native English speaking mariners currently working in the maritime field. Additionally, I wanted to investigate the Maritime English intelligibility from the perspective of the Chinese mariner as the current state of the maritime industry suggests that mariners will increasingly communicate with Chinese NNS as China is increasingly involved in maritime trade worldwide (Fan, Fei, Schriever, \& Fan, 2015; Shen \& Wang, 2010; Tang et al., 2015).

Collection took place on eight separate days over two weeks during normal working hours in an office setting. The offices had closing doors to limit ambient noise; however, noise from outside the office was heard through the closed doors and walls. The offices contained a table and chairs for the interviewee and me along with my recording equipment. Participants listened to the pre-recorded stimuli through small computer speakers. Headphones were specifically not used in order to replicate working 
conditions on board a vessel, ambient noise from crew members talking, the ships' engines running, cargo operations, etc. I recorded the participants with a recording application on a handheld tablet ${ }^{7}$. A small microphone was used on the Kindle Fire the first day of recording, but over the following days, only the internal microphone in the Kindle Fire was used as it was less cumbersome and provided sufficient quality.

\section{Participants}

A convenience sample of 41 volunteer participants (40 male, 1 female) from the two Chinese marine training centers were interviewed based on their willingness to participate in the study. Training center personnel contacted the participants and scheduled their interview times. Participants were all Chinese nationals born, raised and currently living in China. They ranged in age from $22-48$ years old ( mean $=31$ years) and had differing ranks and positions on board the vessel, including 15 participants from the Engineering department, and 26 participants from the Deck department, (see Appendix A for a brief summary of ship position titles and duties). Two participants had served as ratings; their results were exclude from the analysis and is discussed more in the next section. Two participants were pre-service cadets who had not yet been to sea but were projected to go aboard in the coming year; the remaining 37 participants had worked in the maritime industry from $1-25$ years, (mean=8.5 years). Based on IMO requirements, all were required to attain an adequate level of English for their job

\footnotetext{
${ }^{7}$ The hand held tablet was a Kindle Fire, a 7 inch Android tablet with a $1.3 \mathrm{GHz}$ quad-core processor, using a Fire Operating System 5 interface. I used a freeware recording application on the Kindle Fire, the Easy Voice Recorder Pro (version 1.9.1.4).
} 
onboard a merchant vessel. While the participants' level of English varied, most had studied English in formal classroom settings 7-10 years in middle school and high school, and had attended either vocational or university settings with additional English language training. In addition, most had gained English knowledge through practical experience on board the vessel.

\section{Data Collection Procedures}

Pilot Study. A pilot was performed with two NSs and one NNSs (Vietnamese L1) in the U.S. The pilot was limited in that the participants were not of the same L1 background as my intended participants, nor did they have the knowledge of the lexical items used in the phrases. However, the pilot test identified the overall time required for participation: 40-50 minutes per person given the need for participants to read and sign a consent form, fill out a language background questionnaire, and listen and respond to the stimuli. Additionally, the pilot test highlighted questions that needed to be added to the language background questionnaire such as how long the participants had worked in the industry, and in what context they used English onboard the vessels. Procedural adjustments were made to the instructions to make them clearer, and questions regarding the participants' impressions of the speakers were adjusted so that the intelligibility and comprehensibility responses fit into a scale. In addition to these changes suggested by the pilot study, members of my thesis committee highlighted the need for a Chinese translation of the Language Background Questionnaire, instructions for verbatim 
response (Appendix D), and the instructions and questions for the participants' assessment of the speakers' intelligibility and comprehensibility (Appendix E) and the Consent Form (Appendix F). The Chinese translation was provided by a native speaker of Mandarin, a graduate student in the Applied Linguistic Department at Portland State University. The translation was reviewed by my colleague at the training center in China where some further adjustments were made.

Data Collection. Data collection took place during daytime working hours at the training centers in China in an office room with only me and the participant present, as mentioned above. The session was conducted in English. Forty-one participants were interviewed over the course of a 14-day period on 8 separate days. Participants initially read and signed the consent form, (Appendix C: ). After doing so, they were reminded that the session would be recorded, including their verbal consent. Next, they filled out the language background questionnaire (LBQ). As participants worked through the LBQ, I explained or clarified questions as needed. I also went over the LBQ with the participants to ensure I understood their answers.

After the LBQ was completed, each participant listened to one of the four tests (see Table 2) and responded with a verbatim rendering of what they heard. The tests were administered in sequential order as to when the participant arrived, (i.e. Participant 1 heard Test 1, Participant 2 heard Test 2, etc.). A total of 11 participants listened to phrases on Test 1, and 10 listened to Tests 2-4. Prior to listening to the stimuli, I read scripted instructions for the verbatim repetition task of the study while participants also 
read the instruction in English or Chinese, (Appendix D). I demonstrated what the participants should do by reading the phrase, "My cargo is crude oil." and then repeating the phrase out loud mimicking the verbatim response. Additionally, I played one phrase "Mayday, Mayday, Mayday, this is Motor Vessel Naoko" so that they could adjust the volume of the speakers and demonstrate that they understood that they needed to repeat verbatim what they heard. This phrase was repeated up to three times if adjustments to the volume were needed or the participant did not fully understand the directions. After the test phrase was completed and the volume was adjusted to the participant's satisfaction, I played the stimuli once and the participants repeated verbatim what they heard. After playing each recording, I waited until the participant indicated they were ready to proceed. This part of the collection took 2-4 minutes.

Following their oral responses, participants were instructed that they would listen to the same stimuli again and be asked their opinion about how well they understood the phrase, what they thought the phrase meant, their opinion of the speaker's accent, and whether they had ever interacted with anyone with a similar accent (Appendix E). Participants listened to the phrase as many times as they wanted before answering each question. By allowing participants to listen to the phrase multiple times, I believed it affected the validity of their intelligibility ratings. Therefore, I inferred an intelligibility rating based on the accuracy of their verbatim response, and used this rating in my data analysis. This rating is discussed more in the Data Analysis Procedures section. After completion of these questions for all each of the eight test sentences, participants were 
asked their general opinion or impression of Russian, Chinese, Japanese, US and Canadian speakers of English in order to ascertain their attitudes towards those speakers (Appendix G). This session of the interview lasted 25-40 minutes depending on the language ability of the participant and their willingness to talk.

Following the interview, if participants asked about the $\mathrm{L} 1$ of the speaker or what the sentence actually said, I replayed the 8 phrases and told them what the phrase said. Because I assumed the participants did not know each other, I believed their knowledge of the test phrases would not be passed along to others. However, in future studies, this would likely need to be more strictly controlled. Participants were offered a nonmonetary token of appreciation, (a postcard with nature scenes from Oregon), for their participation at the end of the session.

\section{Data Analysis Procedures}

Of the 41 participants, all had served (or would be serving) as officers in either the deck or engine departments on board merchant vessels and had similar education and training backgrounds except two. Because I was interested in the effect of the participants' background on the intelligibility and comprehensibility ratings, I excluded these two participants whom I considered to be outliers. In this sense, outliers were participants who did not share the same background as the other participants, particularly in education and position as officers in either the deck or engine departments. These two participants had served as ratings, that is, non-officer positions of Messman and Able 
Bodied Seaman. By excluding these two outliers, the data which I analyzed consisted of the oral responses to eight phrases from 39 participant totaling 312 phrases and the intelligibility and comprehensibility/accent ratings of those 312 phrases. This subsection of participants included 13 engineers (33\%) and 26 deck officers (67\%), all of whom had been educated at a 4-year maritime university (64\%) or a 3-year maritime vocational school (36\%).

The participants provided their intelligibility ratings for each phrase after they had listened to it during the second part of the session, sometimes more than once. Often their intelligibility rating was a " $5 "=$ "I understood all the words" because after they listened to the phrase multiple times they could identify the words and meaning of the phrase. Because I allowed the participants the opportunity to re-listen to the phrase multiple times prior to their intelligibility rating and comprehensibility rating, I believed their intelligibility rating was not indicative of what they had understood after listening to the phrase one time. Therefore, I chose to infer an intelligibility rating based on the participant's initial verbatim rendering of the phrase. After transcribing the participant's responses, I inferred an intelligibility score based on the same 5-point scale which the participants had used to self-score their understanding of the phrase. I used the following criteria in rating the renderings:

5 - "I understood all the words": The overall meaning of the phrase was not altered by their response. For example, for the first sentence My last port of call was Castine (US speaker), an intelligibility score of 5 was given if the participant 
repeated the sentence exactly as it was spoken, or if all important content words were repeated (function words such as “of” (a.) or even "of call” could be eliminated in "last port of call" (c.). An intelligibility score of 5 was also given if the tense of the verb was changed (a., b., c.), or the participant omitted the copula (c.) as in the following spoken responses:

a. My last port call is Castine. (Preposition "of" omitted; verb changed to present)

b. My last port of call is Castine (verb changed to present)

c. My last port is Castine. ("of call" was not said; verb changed to present), 4 - "I understood most of the words": The verbatim response included or deleted a content word without major effect on the understanding of the sentence (e.g. "Make first tug on starboard quarter." )

3 - "I understood some of the words": Some content words were left out or words were altered or substituted which affected the participant's understanding of the phrase,

2 - "I understood a few words": The participant only understood one or two words, 1 - "I did not understand any words": The participant was unable to produce any of the correct words or stated that they did not understand the phrase.

I calculated whether there existed differences between the four tests with regards to the intelligibility and comprehensibility/accent ratings using a Kruskal-Wallis-H test of 
independent samples. Because my data were nonparametric, I used this test which is considered "the non-parametric equivalent to the one-way between-groups ANOVA, (sic)." (Hatch and Lazaraton, 1991, p. 332). The results indicated that there was no statistically significant difference between the ratings of intelligibility or comprehensibility/accent across the four categories of tests.

\section{Data Analysis}

I calculated and compared the mean ratings of my intelligibility scores and the participant's comprehensibility/accent for 312 sentences to determine which accents of English were the easiest or most difficult to understand (Research Questions 1). To address Research Question 2, "What features of the stimuli made the speech easy or difficult for the Chinese mariner?", I analyzed the verbatim response with the lowest mean ratings and identified areas of reduced intelligibility. I combined these results with the qualitative responses as to what features of the spoken sentence they thought were easy or difficulty to understand. To address research Question 3, “To what degree does education level, experience in the maritime industry, position on board affect the Chinese mariner's ability to understand NNS of English?", I used the Kruskal-Wallis H test to determine the effect of independent variables (IVs) on the intelligibility and comprehensibility/accent ratings (dependent variables (DV)). Using these DVs and the Kruskal-Wallis H test, I measured the effect of participants' education level, their number of years working maritime industry, and their position on board on their responses. 
Additionally, I tested the participant's' age, as well as their self-rating of their ability to communicate (1-7 scale), and the mean of their combined ratings of abilities in speaking, listening, reading, writing, and grammar (1-5 scale, see Appendix C) for any statistical significance on the ratings. The results of these tests will be detailed in the Chapter 4: Results and Analysis under the subheading Research Question 3 and discussed further in Chapter 5 Discussion.

\section{Reliability and Validity}

Reliability. Dörnyei (2007) defines reliability as "the extent to which our measurement instruments and procedures produce consistent results in a given population in different circumstances" (p. 50). One measure of estimating the reliability of tests is the Parallel Test Method (Hatch and Lazaraton, 1991). In my design, I used a Latin Square design for the tests which produced four tests of the same ordered sentence yet with varied order of speakers. As mentioned in Data Analysis Procedures, I conducted a Kruskal-Wallis test of significance on the intelligibility and comprehensibility/accent ratings to assess whether the results between tests were consistent because of the variance of speakers for the sentences. The result of the Kruskal-Wallis test indicated that there was no significant effect of the test on the ratings suggesting that the makeup of the four tests was reliable (intelligibility $\mathrm{p}=.441$; comprehensibility/accent $\mathrm{p}=.154$ ).

During my data collection, I allowed participants to listen to the stimuli multiple times before providing an intelligibility rating and an comprehensibility/accent rating. 
This affected the reliability of the intelligibility ratings. After listening to the sentence multiple times, often the participant would be able to understand the sentence fully, and then indicate that the speaker was highly intelligible (a 5 on my scale). To address this unreliable score, I inferred an intelligibility score for my participants based on their verbatim responses as described in the Data Analysis Procedures section. In future studies, participants should verbalize their intelligibility ratings immediately after the verbatim response. In so doing, the reliability of the participant's intelligibility score would increase. To increase the reliability of my inferred ratings of intelligibility, I scored the responses during two different sessions four days apart. A Cohen's Kappa (k) test was run to determine the intra-rater agreement of my inferred intelligibility ratings. There was a high level of agreement between my ratings, $\kappa=.935$.

Validity. The verbatim response test I designed was constructed to measure the intelligbility, comprehensibility and interpretability of Maritme English as perceived by Chinese mariners. In fact, the test measured the intelligibility of a small number of SMCPs used primarily by deck officers. The content validity of the test I designed is not necessarily a representative sample of Maritime English, but only one subset of the language used on board a vessel, in specific contexts. This affected the face validity of my study, and this fact was not realized until I had begun collection. The phrases I chose were not used by all mariners, even though arguably all mariners should know the lexical items contained within the sample of 'Standard Marine Communication Phrases' I chose as stimuli. The phrases were all commands or statements used on the bridge of the vessel 
for navigational purposes and not often, if ever, encountered or used by the engineering officers.. However, what this research indeed offers, is that the English needs differ signiifcantly between mariners who work on the deck and in the engine room. Further research studies should account for this and limit participation in studies by position on board the vessel. Yet, the fact that my stimuli were skewed to deck officers was highlighted because I used a mixed-method approach and provided opportunity for my participants to respond to questions about the stimuli after they had heard the phrases. A mixed-method approach which draws on both qualitative and quantitative analysis can improve the validity of research as the findings are corroborated through triangulation. (Dörnyei, 2007)

The internal validity of the test for deck officers has high confidence. Two speakers from each L1 were selected to control for speech variablility between speakers, and all male speakers were chosen specfiically to control for gender. The modified Latin Square design allowed for the use of four tests, which varied the order of speakers for each test but kept the sentences all in the same order. Every fourth particpaint heard the same test which decreased the likelihood of participants knowing which speaker was saying which sentence if the particpants talked to each other. However, it is plausible that because the order of the phrases remained the same despite the variance of speaker on each test, participants may have known in advance what to expect. 


\section{Chapter 4 Results and Analysis}

This chapter will explore the results of my analysis as it pertains to the research questions. Throughout my analysis, I used the Kruskal-Wallis H test of significance with $\mathrm{p}=.05$. Post hoc analysis of paired comparisons was completed with the Mann-Whitney test with adjusted significance values using the Bonferroni correction for multiple tests. All statistical calculations were completed using IBM's SPSS version 24 (IBM, 2016).

\section{Research Question 1}

\section{For Chinese mariners, which accents of English are the easiest or most difficult to understand and why? How do the participants characterize their ease or difficulty in understanding?}

The categories of Speaker L1 (Chinese, English, Japanese, and Russian), had a significant between-group effect on the intelligibility rating $(\mathrm{p}=.009)$ and accent/ comprehensibility ratings $(\mathrm{p}=0.001)$. Since the $\mathrm{p}$-value was less than .05 for both it suggests that L1 of the speaker had an effect on the ability of the participant to understand the phrase. The post hoc Mann-Whitney test showed that the Chinese L1 speakers were significantly more intelligible to the participants than the Russian (.02) ${ }^{8}$ and the Japanese (.03). Additionally, the post hoc test showed that the accent of the native English speakers was more comprehensible than the Japanese (.017). The Chinese accents were more comprehensible than the Japanese (.001) and Russian (.014).

\footnotetext{
${ }^{8}$ SPSS v. 24 adjusted the significance values using the Bonferroni correction for multiple tests.
} 
Next, I calculated the mean of my intelligibility rating as well as the participants' comprehensibility/accent ratings by L1 of the speakers to determine which accents were the easiest or most difficult to understand. The results of these calculations indicated that the Chinese speakers were most intelligible $(\mathrm{m}=4.19 / 5)$ and their comprehensibility rating $(m=4.51)$ suggests they were easiest to understand. Table 3 summarizes these results. Table 3 Intelligibility and Comprehensibility Ratings Mean Results

\section{Speaker L1 Intelligibility Comprehensibility}

\begin{tabular}{lll} 
Chinese & 4.19 & 4.51 \\
English & 3.95 & 4.36 \\
Russian & 3.62 & 4.03 \\
Japanese & 3.59 & 3.71 \\
\hline$n=78$ for all SpeakerL1's. & &
\end{tabular}

The final question I asked the participants was the country, or first language of the speaker. I wanted to gain an understanding of whether thee participants where familiar with the speaker's accent (such as by listening to radio, TV or watching movies) or had interacted with persons speaking with this accent. Bent and Bradlow ( 2003) indicated in their research that a matched interlanguage intelligibility benefit existed with their participants, as well as an 'unmatched' interlanguage intelligibility benefit. An unmatched interlanguage intelligibility benefit is a benefit gained by NNS who interact with other NNS; that is, NNS speech is perceived as easier to understand than NS speech by NNS listeners. I asked my participants to identify the L1 of the speaker to determine whether their familiarity with the speakers might affect the intelligibility or comprehensibility of the phrase. Overall, the participants were able to accurately identify 
the $\mathrm{L} 1$ of the speaker just $22 \%$ of the time. They were able to identify the Chinese speakers $56 \%$ of the time. Table 4 shows the percentage of accuracy with which the participants were able to identify the L1 of the speaker. The table shows the Speaker L1 in the first column, followed by the number of instances which the participants identified the speaker with the correct or incorrect L1 and the percentage.

Table 4 L1 of Speaker Correctly Identified by Participant

\begin{tabular}{lcc}
\hline Speaker L1 & Frequency & Percent \\
Chinese & $44 / 78$ & $56.4 \%$ \\
English & $16 / 78$ & $20.5 \%$ \\
Japanese & $6 / 78$ & $7.7 \%$ \\
Russian & $3 / 78$ & $3.8 \%$ \\
\hline
\end{tabular}

The accuracy with which the participants were able to identify the speakers L1 reflects a similar order as their intelligibly and comprehensibility rating with one exception. The participants were able to identify Japanese speakers slightly more often than the Russian speakers whereas they rated the intelligibility and comprehensibility/accent of the Japanese lower than Russian. When the participants were asked to characterize the ease or difficulty they had in understanding the speakers, they most commonly answered that either the pronunciation was not clear or it was different from what they were expecting. Additionally, many participants reported that the speakers' rate of speech was too fast. The rate of speech of the speakers was not considered within the scope of this research; however the effect of continuous speech on the phonetics of the stimuli was addressed in Research Question 2. 


\section{Research Question 2}

To address Research Question 2, "What features of the stimuli made the speech easy or difficult for the Chinese mariner?", I first analyzed whether the sentences or the individual speaker had a significant effect on the overall intelligibility or comprehensibility/accent. The sentences showed a statistically significant between-group difference for the intelligibility rating $\left(\mathrm{N}=312, \chi^{2}[\mathrm{df}=7]=28.581, \mathrm{p}=0.001\right)$ and a statistically significant between-group difference for comprehensibility/accent rating $\left(\mathrm{N}=312, \chi^{2}[\mathrm{df}=7]=16.903, \mathrm{p}=0.018\right)$ indicating the individual sentences did affect those ratings respectively.

I used the Mann-Whitney post-hoc analysis pair-wise comparison test to identify which sentences were more intelligible. The post-hoc analysis showed that the sentence, 'The pilot boat is approaching.' rated significantly higher than 5 of the other sentences. See Table 5 for the results of the post-hoc analysis by sentence for the intelligibility ratings. 
Table 5 Post-hoc pair-wise comparisons of intelligibility rating by sentence

\begin{tabular}{|c|c|c|c|c|}
\hline Sentence & $\begin{array}{c}\text { Adjusted } \\
\text { Significance }\end{array}$ & $\begin{array}{c}\text { Mean } \\
\text { Intelligibility } \\
\text { Rating }\end{array}$ & $\begin{array}{l}\text { \# of } \\
\text { Words }\end{array}$ & $\begin{array}{c}\text { \# of } \\
\text { Syllables }\end{array}$ \\
\hline $\begin{array}{l}\text { S6-The pilot boat is } \\
\text { approaching. }\end{array}$ & .062 & 4.64 & 5 & 8 \\
\hline $\begin{array}{l}\text { S8-The TCPA is thirteen } \\
\text { minutes }\end{array}$ & .062 & 3.85 & 8 & 10 \\
\hline $\mathrm{S} 1{ }^{*}$-My last port of call was .... & .585 & 4.15 & $7-8$ & $8-10$ \\
\hline $\begin{array}{l}\text { S7-Put seven shackles in the } \\
\text { water. }\end{array}$ & .010 & 3.74 & 6 & 9 \\
\hline $\begin{array}{l}\text { S3-Rig the pilot ladder one } \\
\text { meter above water. }\end{array}$ & .009 & 3.69 & 8 & 13 \\
\hline $\begin{array}{l}\text { S4-My present course is one- } \\
\text { three-five degrees. }\end{array}$ & .002 & 3.59 & 8 & 10 \\
\hline $\begin{array}{l}\text { S5-We will use the starboard } \\
\text { anchor. }\end{array}$ & .002 & 3.59 & 6 & 8 \\
\hline $\begin{array}{l}\text { S2-Make fast the tug on the } \\
\text { starboard quarter. }\end{array}$ & .001 & 3.44 & 8 & 10 \\
\hline Overall mean for all sentences & & 3.84 & & \\
\hline
\end{tabular}

*The last word (place name) differed by L1 of speaker (see Table 1) $n=39$ for each sentence.

Since the tests of significance indicated that the individual sentences and the individual speakers affected the intelligibility ratings, I analyzed the means of the intelligibility ratings by sentence to determine which sentences the participants considered the least intelligible. Then, I calculated the overall mean intelligibility rating for each of the speakers. Finally, I looked at the verbatim responses based on the lowest intelligibility ratings by sentence and speaker to determine where and what the areas of reduced intelligibility may be.

The results of the mean intelligibility rating analysis by sentence indicated that Sentence 2, "Make fast the tug on the starboard quarter", was the least intelligible 
sentence and Sentence 6, "The pilot boat is approaching", was the most intelligible one. Not only was the L1 of the speaker but also the sentence itself significant in determining intelligibility.

The results of the mean intelligibility rating analysis by speaker indicated that Chinese Speaker 2 was most intelligible and Japanese Speaker 2 was least intelligible; the results are displayed in Table 6 . The individual speaker intelligibility ratings highlight the effect of individual differences of speech. It should be noted that these results differ from the speaker L1 results showed in Table 3 which portrays the combined means of the two speakers from each L1. In Table 6, the speakers are ordered by decreasing intelligibility once again.

Table 6 Intelligibility Rating by Speaker L1

\begin{tabular}{|c|c|c|}
\hline Speaker & Mean Ratings & $\begin{array}{l}\text { Standard } \\
\text { Deviation }\end{array}$ \\
\hline Chinese Speaker 2 & 4.31 & 1.20 \\
\hline Canadian Speaker & 4.15 & 1.14 \\
\hline Chinese Speaker 1 & 4.08 & 1.22 \\
\hline Japanese Speaker 1 & 3.90 & 1.35 \\
\hline Russian Speaker 2 & 3.77 & 1.44 \\
\hline U.S. Speaker & 3.74 & 1.37 \\
\hline Russian Speaker 1 & 3.46 & 1.31 \\
\hline Japanese Speaker 2 & 3.28 & 1.46 \\
\hline
\end{tabular}

The influence of the speaker L1 affecting the intelligibility of the phrase for the participant was most noticeable in the pronunciation of place names in Sentence 1. To illustrate this point, only one of nine participants who listened to the Russian speaker was able to parse [scnt 'piz.b.gg] as "St. Petersburg". In three of the phrases, the initial word(s) 
were unclear for the participants and because participants missed the first word(s), they were often unable to create meaning for the remaining words in the phrase. The spoken

numbers within three sentences were also challenging; either numbers were replaced with other words, ("some" for "seven"), the numbers were switched ("one, five, three" for “one, three, five"), or a different number was heard, ("thirty" for "thirteen"). Finally when the Russian speaker said "starboard anchor", the /d/ in starboard was devoiced and the /t/ was coarticulated with <anchor> causing the word "tank" or "tanker" to be heard. See Appendix $\mathrm{H}$ for additional examples for each sentence.

The participant background factors that were statistically significant in the participants' ratings will be discussed in the next section.

\section{Research Question 3}

As mentioned in the previous section, the participants told me during the collection that the SMCP phrases I asked them listen to were all deck commands or statements. They indicated that their position on board the vessel impacted intelligibility, comprehensibility and interpretability of the Standard Marine Communication Phrases that they heard. To understand these phenomena more clearly, I performed a series of Kruskal-Wallis statistical tests $(\mathrm{p}<.05)$ with post-hoc Mann-Whitney to determine what other variables in the participants background effected their intelligibility and comprehensibility/accent ratings as well as if the participants' position had a statistically significant effect on those ratings. All statistical tests were performed using SPSS v. 24 
(IBM, 2016). I used the intelligibility and comprehensibility/accent ratings as dependent variables. For the independent variables, I used the participants' position on board the vessel (deck or engineer), their education level (vocational or university), and the number of years in the industry to establish. The findings address the third research question, "Does education level, experience in the maritime industry, position on board affect the Chinese mariner's ability to understand NNS of English?”. A summary of the tests ran on which independent variables and their respective significance is in Table 7.

Table 7 Variables and their significance on Intelligibility Ratings

\begin{tabular}{|l|l|}
\hline Not Statistically Significant & Statistically Significant \\
\hline Education Level $(\mathrm{p}=0.863)$ & Position on board vessel $(\mathrm{p}=.001)$ \\
\hline Number of Years in Industry $(\mathrm{p}=.076)$ & Speaker L1 $((\mathrm{p}=.009)$ \\
\hline Test \# $(\mathrm{p}=.441)$ & Sentence number $(\mathrm{p}=0.001)$ \\
\hline
\end{tabular}

The results indicated that the participant's position had a significant effect on the intelligibility $(\mathrm{p}=.001)$ and comprehensibility/accent $(\mathrm{p}=.001)$ ratings. The participants' education level did not have a significant effect on the overall ratings of intelligibility $(\mathrm{p}=0.863)$, or the comprehensibility/accent rating $(\mathrm{p}=.966)$. Further, when I split the data by L1 of the speaker, the distribution of intelligibility and accent was the same across the categories of education for each speaker L1. The participant's number of years in the maritime industry had no significant effect on the intelligibility rating (p 
$=.076)$. On the other hand, the years of maritime industry experience did have significance on the comprehensibility/accent rating $(\mathrm{p}=.043)$.

The significance of these findings, i.e., that a participant's position on the vessel significantly affects their understanding of English will be discussed in the next section. 


\section{Chapter 5 Discussion}

\section{Overview}

The purpose of this study was to investigate the intelligibility of Maritme English, more specificlaly, Standard Marine Communication Phrases by Chinese mariners. As the results suggest, many factors contributed to the ratings; however I will focus my discussion on how familiarity with topic (via position), as well as accent familiarity played a significant role in my findings. Based on my analysis, the most salient aspect of the participant's background which influenced their intelligibility and comprehensibility/accent ratings was their position on board the vessel. Education level (university or vocational) had no statistically significant effect on a participant's ability to understand the utterance; likewise, the number of years in the maritime industry had no significant effect. However, my findings did suggest that familiarity with the speaker L1 (accent familiarity) as well as specific sentences (topic knowledge), did have significance.

\section{Accent Familiarity}

The first research question asks which accents for Chinese mariners were the easiest of most difficult to understand and why. Based on their ratings, the participants were best able to understand the Chinese speakers, the English speakers, Russians, and finally the Japanese, in that order. These findings support the premise that accent familiarity, or the interlanguage speech intelligibility benefit (Bent and Bradlow, 2003) 
played a role in a listener's ability to understand an utterance. That is, my Chinese participants were best able to understand speakers of English whose L1 was also Chinese. However, unlike the Bent and Bradlow (2003) study, my participants did not demonstrate a 'non-matched' interlanguage benefit. The accents of the Japanese and Russian were not as easily understood by the Chinese while the Chinese speakers (a 'matched' interlanguage benefit), and native speakers were more easily understood.

In my study, participants were not apprised of the speaker's nationality or L1. When asked which language the speaker spoke as a native language and whether they interacted with speakers with this accent, they were highly incorrect as to the L1 of the speaker. An inaccurate characterization, of course, made their discussion mostly irrelevant of whether they interacted with someone with this accent in the past. The exception to this statement was their identification of Chinese speakers. The participants were able to identify Chinese speaker 2 as a native Chinese (Mandarin) speaker nearly $77 \%$ of the time $(n=39)$ while they identified the L1 of Chinese speaker 1 only $36 \%$ of the time $(n=39)$. It is interesting to note, however, the participants indicated that they did not regularly interact with other Chinese speakers in English, and instead use their native language to communicate. A few participants indicated that the exception to this was when their vessel entered a foreign port and English was the regular medium, it was necessary to speak with fellow crewmembers. In this instance, even an all-Chinse crew would speak English among themselves. This discrepancy in their identification of the L1, suggests that role of accent familiarity may not play as large a role as previously thought. 
In fact, as the number of NNS increase who are influenced by varieties of English other than Kachruvian inner circle varieties (American, British, Australian, Canadian, or New Zealand), 'accents' of English may also take on varieties. For instance, a Russian mariner who served aboard vessels with Indian mariners may acquire the prosodic features of the Indian variety of English and thus carry an Indian speaker accent rather than what may be termed a characteristic Russian accent.

\section{Features Affecting Ease or Difficult of Intelligibly}

Regarding the reason for the ease or difficulty with which the participants understood the Chinese speakers, most commonly cited was the clarity of speech as well as knowledge of the phrases. Analysis of the three most unintelligible sentences revealed several semantic and phonetic factors that were problematic. What was most striking about the intelligibility rating of Sentence 2, "Make fast the tug on the starboard quarter", was that of the 18 verbatim responses which had a low intelligibility rating ( 3 or lower), 13 came from the engineering department, the entirety of the engineering component! The majority of the misunderstanding occurred at the beginning of the phrase suggesting that the collocation of "make fast" was not known or used frequently. Even though this is a common lexical phrase in Maritime English meaning 'to fasten or make tight', engineers were unable to parse this phrase from the sentence regardless of the L1 of the speaker. Not understanding this word likely hindered them in interpreting the entire phrase. Half of the participants were unable to understand any other words in the phrase 
except "starboard". As already indicated, previous knowledge likely played a role. From the participants with intelligibility score of 5 for this sentence, a common response was that this phrase was commonly used; they had either said it every day or responded to the command frequently. Additional examples of the areas of which caused difficulty for the participants to understand for each sentence are sentence are in Table 7 and further explanation can be found in Appendix $\mathrm{H}$.

Table 8 Areas of Difficulty/Ease for Participants by Sentence.

\begin{tabular}{|c|c|c|}
\hline Sentence & $\begin{array}{l}\text { Features affecting } \\
\text { Ease or Difficult of } \\
\text { Intelligibly }\end{array}$ & Implication \\
\hline $\begin{array}{l}\text { 1. My last port of call was } \\
\text { St. Petersburg. }\end{array}$ & Name of port & Influence of L1 \\
\hline $\begin{array}{l}\text { 2. Make fast the tug on } \\
\text { the starboard quarter. }\end{array}$ & "Make fast" & Unknown lexical items \\
\hline $\begin{array}{l}\text { 3. Rig the pilot ladder one } \\
\text { meter above water. }\end{array}$ & "Rig" & Unknown lexical item \\
\hline $\begin{array}{l}\text { 4. My present course is } \\
\text { one three five degrees. }\end{array}$ & $\begin{array}{l}\text { "one three five" } \\
\text { (numbers dropped or } \\
\text { reverse ordered) }\end{array}$ & Spoken numbers \\
\hline $\begin{array}{l}\text { 5. We will use the } \\
\text { starboard anchor. }\end{array}$ & $\begin{array}{l}\text { "We will use"- } \\
\text { (question versus } \\
\text { statement) } \\
\text { "starboard anchor" - } \\
\text { /d/->/t/ devoicing, } \\
\text { and assimilation of /t/ } \\
\text { to 'anchor' }\end{array}$ & $\begin{array}{l}\text { Prosodic features, intonation } \\
\text { Influence of L1 }\end{array}$ \\
\hline $\begin{array}{l}\text { 6. The pilot boat is } \\
\text { approaching. }\end{array}$ & $\begin{array}{l}33 \text { of } 39 \text { rated } 5 \text { for } \\
\text { intelligibility }\end{array}$ & $\begin{array}{l}\text { Shortest sentence, fewest } \\
\text { syllables }\end{array}$ \\
\hline $\begin{array}{l}\text { 7. Put seven shackles in } \\
\text { the water. }\end{array}$ & "seven shackles" & Unknown lexical items \\
\hline $\begin{array}{l}\text { 8. The TCPA is } 13 \\
\text { minutes }\end{array}$ & $\begin{array}{l}\text { "TCPA" } \\
\text { "13 minutes" } \\
\text { (13 versus } 30)\end{array}$ & $\begin{array}{l}\text { Unknown lexical item } \\
\text { Spoken numbers }\end{array}$ \\
\hline
\end{tabular}




\section{Topic Knowledge}

As mentioned previously, the stimuli were skewed in favor of the participants who worked in the deck department. For the deck officers in my study, these represented authentic speech stimuli. For the engineering officers, they did not. These phrases were all real-world Maritime English phrases taken from the SMCP, which would have been said or heard on the bridge of a vessel, the domain of the deck officers and deck crew. But, as Sampson and Zhao (2003) acknowledge,

Despite the 'simplification', the number of phrases covered by SMCP is likely to be a great challenge to seafarers who are not native English speakers. In its present form, the SMCP consists of 114 pages (a total of more than 3,000 phrases) with an additional 15 pages of explanatory notes. (p. 33)

This suggests that as exhaustive as the SMCP may be, simply studying the SMCP or using SMCP as the basis for Maritime English instruction may not provide the learners with the authentic lexical or semantic knowledge they need in order to understand Maritime English in a real-world setting. More significantly, the phrases used in my study do not represent the 'maritime English' used by engineers on board vessels. Several participants who were engineers confirmed this sentiment as they commented that the phrases were typically not heard during the course of their work on board the vessel. Conversely, the participants who worked in the deck department said that the phrases were easy to understand because that was part of their job. Deck officers had heard, responded to the phrase, or used the phrase nearly every day. While the fact that the 
stimuli were skewed in favor of deck officers is certainly a drawback to my study, it does significantly highlight the role that position on board a vessel plays in how mariners are able to understand various speakers of English. To this end, there exists a need for authentic English instruction based on the English language needs of each position on board the vessel. My stimuli were taken from phrases of the SMCP, which was drafted as codified expressions to facilitate navigation. This is not sufficient as the sole document to instruct engineers or other non-navigation positions on board a vessel in the English language necessary to fulfill their duties.

Therefore, language expertise acquired by experience, or in the case of this study, the context in which the participant is situated with respect to their language use (i.e., position on board the vessel) seemed to outweigh accent familiarity. One participant remarked in response to what made the accent easy to understand:

This is the working language so we using this language many times.... Because you are doing many times of this job so once they give you some, little bit of information, like "make fast the tug", not the full of the sentence, you can understand. (Participant interview with Holland, 2016)

Here the participant was referring to his familiarity with the lexical items as well as the experiential context which provided the 'ease' in understanding the accent. He suggested in his responses that the accent of the speaker did not make a difference once one knew the job. In fact, this sentiment was repeated by others. Another participant indicated that regardless of what was understood over the radio, he would know by situational context what needed to be done. For instance, as a vessel enters or departs port, a pilot will come 
on board the vessel. Deck officers and deck crew will know that as the pilot boat is approaching, the pilot ladder must be lowered so that the pilot can come aboard.

Therefore, Sentence 3: "Rig the pilot ladder one meter above water", could be highly unintelligible due to the speaker's pronunciation, the effect of radio transmission, or the interference from vessel operations, yet the illocutionary force of the phrase would be known based on context. Past experience, prior knowledge of the working environment and procedures would all determine the intelligibility and comprehensibility of the phrase. One participant remarked that he need only understand one or two words and he would know what to do, suggesting that in addition to his position on board the vessel, the context in which the phrase would be made was known and recognizable.

\section{Pedagogical Implications}

In light of this study, several pedagogical recommendations emerge. The first is that pre-service Maritime Education Training centers (academies, universities, and vocational schools) should incorporate a holistic English language-learning approach with content. This approach would not segregate English from the context of the other classes, but in fact be intertwined with the navigation and engineering courses as well as with experience on board vessels. In linguistic literature in English for Academic Purposes, this approach has been in use for at least 3 decades. Snow and Brinton (1988), assessed the integrated approach to language skills and content based curriculum at the University of California, Los Angeles (UCLA) Freshman Summer Program (FSP). 
Incoming freshman were afforded the opportunity to introductory level content courses, such as political science, as well as 12-14 hours of language classes that linked language learning with the content course. Their first study solicited input from former students in the UCLA FSP and the feedback from the participants was supportive of the program. The positive feedback indicated the students benefited from subject courses intertwined with language courses..

Similarly, this approach to teaching Maritime English has been adopted recently by at least one maritime university which introduced the concept of 'twinning' English language training into specific discipline study. In the Marine Engineering Programme at Chalmers University of Technology (Gothenburg, Sweden), Maritime English instructors and Engineer instructors have designed courses which integrate and overlap the teaching and learning activities of both disciplines, (Eliasson \& Gabrielli, 2011; Gabrielli, Gabrielli \& Pahlm 2012) They write:

One of the greatest challenges in teaching good communication skills and what that means for a marine engineer or any seafarer, is to design content-based language learning activities which integrate Maritime English along with the requirements of the engineering profession. The design of such a curriculum supports the development of communicative skills by enabling students to recognize any given communicative dimension of their profession in a natural working environment. (Eliasson \& Gabrielli, 2015, p 62)

In their pre-service training institution, the contextualization of English language learning is beginning to take shape. Similar to the UCLA FSP student responses, the Marine Engineering Program at Chalmers University of Technology also received positive 
feedback from students in response to the 'twinned' classes. More of this integrated, communicative approach to teaching language in context and content could reinforce language learning and have positive impact on the communicative ability of mariners.

The recommendation of specific training by discipline or position on board the vessel is also evidenced by the IMO's Model Course for English 3.1.7 (IMO, 2014). This model course divides Maritime English into two sections: General Maritime English and Specialized Maritime English. The General Maritime English section is designed to introduce the Maritime English itself: "The overall purpose of GME instruction is to teach the language for the language's sake through the application, for example, of maritime scenarios," (IMO, 2014, p. 6). Prior to taking a GME course, the authors of the model course suggests that learners should have achieved an elementary level of English and be able to use English for basic everyday needs. The second section, Specialized Maritime English, consists of six parts aimed at achieving "the effective communication competences of specific maritime duties through the application of the English language" (p. 7). This section includes specific English language instruction geared towards navigation watch officers (deck officers, pp. 128-145), and engineering watch office among others (pp. 146-159). The model course authors echo the recommendation that it is beneficial for students if English is incorporated into the technical maritime subjects as well as in separate English classes. (pp. 146-147).

This approach to 'twinning', that is integrating the teaching of English into content based courses, as well as assessing English for mariners based on skill implies a 
level of maritime subject matter competency on the part of the English instructor. Maritime English instructor competency is outside the scope of my research, but has been widely addressed in previous research, (Cole, Pritchard, and Trenkner, 2007).

Secondly, the same 'twinning' concept must be applied to post-service or inservice training which mariners are required to pursue. The required refresher courses for GMDSS $^{9}$ or courses necessary to advance such as the Bridge Resource Management class should include elements of the 'twinning' concept. In so doing, instructors and students could maximize their input and takeaway from the class. Again as an example of this, the IMO's Model Course for English 3.1.7 Part 2.5 was specifically designed for GMDSS operators and focuses on the written and oral communication to transmitting or receiving information via the GMDSS system (IMO, 2014, pp. 186-192). What remains to be done is to translate the 'model-course' into existing course material to enhance the English instruction at various MET institutions worldwide.

Thirdly, in assessing language skills of mariners, assessment measures must be limited either to general Maritime English, or ensure that authentic material is used for all position on board the vessel. In other words, SMCP navigation phrases do not represent authentic material for marine engineers, and efforts must be made to ensure that marine engineers are assessed on the language of their position expertise.

Finally, it should be acknowledged that language learning is a process which takes time and does not end when the student leaves the classroom. Thus, life-long

\footnotetext{
${ }^{9}$ GMDSS - Global Maritime Distress and Safety System - an international system which includes safety procedures, equipment and communication protocols aimed at increasing safety and making it easier to recue vessels, ships and aircraft in distress
} 
language learning techniques and communication skills should be taught early on in the career of mariners. Language learning techniques include strategies for continued vocabulary learning, as well as enhanced communication skills necessary to negotiate meaning between interlocutors. To paraphrase one participant, each vessel brings new communication challenges as the 'language' differs based on the L1 make-up of the crew. New varieties of Englishes therefore must be mastered, new words or pronunciation patterns must be learned as the vessel hosts a continuously evolving and dynamic linguistic environment as crew sign-off and sign-on to the vessel at differing times. Exposing cadets to a variety of accents of English would greatly enhance their ability to understand and comprehend all speakers of English with whom they interact.

\section{Limitations and Suggestions for Future Research}

Several factors limit how generalizable the results may be. This study was conducted with only a limited number of participants $(n=39)$ from one language background, Mandarin Chinese. Therefore, while the results can be generalizable to a similar population of Chinese mariners, they are not necessarily generalizable across the whole population of mariners. Also, this study incorporated stimuli from speakers of only three L1's other than English, and a broader study using multiple NNS L1 stimuli and additional NNS L1 listeners would be worthwhile. Additional studies similar to Smith and Rafiqzad's (1979) expansive study which used speakers from are needed. Furthermore, this study was conducted with stimuli which were pre-recorded, not drawn 
from real-world situations. The poor voice quality over radios with background noise and radio transmission interference is a significant factor in real-world communication. Using authentic radio transmissions as stimuli may provide different results, particularly among the deck officers. The effect of experience may be a significant factor with realworld communications. Finally, the subject matter of the stimuli favored mariners who worked on deck over those who worked in the engine department. The fact that the stimuli were skewed to the deck members was apparent during the interviews and evident in the rating results. Limiting participants based on position would eliminate this confounding variable; however, it is apparent that studies of maritime English need to include appropriate stimuli for not only deck officers but engineering staff alike. 


\section{Chapter 6 Conclusion}

This study shows that understanding Maritime English is highly context-based, especially as to the position of the user. A reoccurring theme was the difference in intelligibility ratings between the participants who held positions in the deck department versus those who held positions in the engine room. This finding highlights that intelligibility of an utterance is a complex phenomenon that includes phonetic features of the utterance made by the speaker, as well as the ability on the part of the listener to parse the phonemes into words that are known and have meaning. The SMCP regardless of its expansive list of phrases, does not address the needs of all mariners. Position specific language learning that is relevant and contextualized is needed. At a minimum, posteducation and mid-career English classes which are taught in conjunction with or intertwined with other required course would be beneficial for the mariner. These classes should be highly contextualized and streamlined for the individuals and based on the specific context in which the mariner is situated. Pairing or "twinning" required courses such as Bridge Resource Management with English classes may well advance the linguistic ability of mariners.

Yet, this language training cannot be conducted adequately without the knowledge of marine engineering entering the foray of the language teaching expert. Certainly, the additional study of Maritime English in working situations on vessels is needed. Further research is needed in this specialized field to determine the how 
mariners are using English versus what is taught in Maritime Education and Training (MET) institutions or what is prescribed in the SMCP. The data from my study can be further analyzed to understand how participants use English in their activities on board the vessel, such as giving or receiving commands, writing emails or filling out forms. A study using this data could be insightful for MET institutions creating curricula. Additionally, my data could be analyzed more in-depth by participant position to characterize the difficulties encountered in understanding the phrases be it phonetic, semantic, prosodic or some other influence. To evaluate and improve NNS-to-NNS communication is well worth the effort and continued research in this field should be undertaken.

The industry continues to grow not only in volume of vessels and cargo transported across the world's waterways, but also in terms of the number of mariners of varied cultural and linguistic backgrounds and of the multi-cultural and multi-linguistic environments in which they find themselves. The number of NNS within the industry grows, and the situation presents a rich opportunity to study real-world communication between these English language learners. The ability to speak clearly, concisely and without ambiguity is absolutely necessary in the maritime industry, and is stated as such in internationally binding agreements. Likewise, the ability to comprehend and correctly interpret an utterance is crucial to avoid loss of life and/or cargo, as well as prevent environmental disasters. Finally, it is imperative that all in the maritime field work to establish a 'lingua franca' of maritime English that truly is global and used. It cannot be 
that only non-native speakers' must use this codified language, but native speakers in seagoing capacities as well as land-based maritime position must be attuned to the need for speech practice that can be readily understood by all with whom they come in contact. 


\section{References}

Bakr, M. (1979). A Linguistic Approach to Marine Communication. Journal of Navigation, 32(2), 171-179.

Baltic and International Maritime Council (BIMCO),(2010). Highlights. Manpower 2010 update: The worldwide demand for and supply of seafarers.

Becker, M. \& Kluge, D. (2014). Intelligibility of English as a Lingua Franca (ELF): Perception by Speakers of Brazilian Portuguese. Proceedings of the International Symposium on the Acquisition of Second Language Speech Concordia Working Papers in Applied Linguistics, 5, 50-57. Retrieved from http://doe.concordia.ca/copal/documents/5_Becker_Kluge_Vol5.pdf.

Bent, T., \& Bradlow, A. R. (2003). The interlanguage speech intelligibility benefit. The Journal of the Acoustical Society of America, 114(3), 1600-1610.

Berns, M. (2008). World Englishes, English as a lingua franca, and intelligibility. World Englishes, 27(3-4), 327-334.

Choi, S, \& Park, J. (2015). Lingua franca core for Maritime English pronunciation teaching. In Proceedings of the International Maritime English Conference $(I M E C)-27,40-50$.

Cole, C., Pritchard, B., \& Trenkner, P. (2007). Maritime English instruction-ensuring instructors' competence. Ibérica, (14), 123-147.

Cole, C., \& Trenkner, P. (2008). The yardstick for maritime English STCW assessment purposes. In Proceedings of IMLA 16th Conference, 163-173. 
Cole, C. W., \& Trenkner, P. (2012). Whither Maritime English?-2012. In Proceedings of the 24nd International Maritime English Conference, 3-18.

Couper, A. (2000). Implications of maritime globalization for the crews of merchant ships. Journal for Maritime Research, 2(1), 1-8.

Demydenko, N. (2010). International Standards of Maritime English as a Means to Improve Safety at Sea. Journal of Marine Technology and Environment, 1, 91-94.

Demydenko, N. (2012). Teaching maritime English: a linguistic approach. Journal of Shipping and Ocean Engineering, 2(4), 249.

Dörnyei, Z. (2007). Research methods in applied linguistics : Quantitative, qualitative, and mixed methodologies. Oxford ; New York, N.Y.: Oxford University Press.

Dirgayasa, I. W. (2014). Survey of English Teaching and Learning Process in Maritime Education and Training in Indonesia: A Case Study in Private MET in Indonesia. English Language Teaching, 7(7), 111.

Dževerdanović-Pejovic, M. (2013). Discourse of VHF Communication at Sea and the Intercultural Aspect. International Journal for Traffic and Transport Engineering, 3(4), 377-396.

Eliasson, J. and Gabrielli, A. (2011). Language taught as language used, integrating Maritime English in the teaching of mechanical engineering. In Proceedings of the 23nd International Maritime English Conference, 114-119.

Eliasson, J. and Gabrielli, A. (2015). The design of Maritime Education and Training: Progression and integration in Maritime English courses, for a Global Maritime 
Approach. In Proceedings of the 27th International Maritime English Conference, $62-73$.

Fan, L., Fei, D., Schriever, U., Fan, S. (2015). Communication challenges to Maritime English education and training in China in the modern shipping world. Presented at the Master Mariners' Congress 2015 at University of Tasmania, Australian Maritime College, Launceston, 13-15 Aril 2015. Retrieved from http://www.mastermariners2015.com.au/wp-content/uploads/2015/04/Fan-FullPaper.pdf

Franceschi, D. (2014). The features of Maritime English Discourse. International Journal of English Linguistics, 4(2), 78-87.

Gabrieli C., Gabrielli A., \& Pahlm H. (2012). Engineering ME: A symbiosis between language, communication and an alligator spanner wrench? In Proceedings of the 24th International Maritime English Conference, 41-52.

Gang, L. (2008). It's high time SMCP got well underway in China. In Proceedings of the 20th International Maritime English Conference, 214-220.

Gooskens, C., (2013) Methods for measuring intelligibility of closely related language varieties. In R. Bayley \& C. Lucas (Eds.), Handbook of sociolinguistics. Oxford

Hatch, E. M., \& Lazaraton, A. (1991). The research manual: Design and statistics for applied linguistics. New York, NY: Newbury House Publishers.

IBM Corp. Released 2016. IBM SPSS Statistics for Windows, Version 24.0. Armonk, NY: IBM Corp 
International Maritime Organization. (1978). Standard Marine Navigational Vocabulary $(S M N V)$. London: IMO. Retrieved from http://www.imo.org/OurWork/HumanElement/Pages/STCW-Conv-LINK.aspx International Maritime Organization (2002) IMO Standard Marine Communication Phrases. Retrieved from https://mcanet.mcga.gov.uk/public/c4/solasv/resolutions/A918\%2822\%29.pdf International Maritime Organization. (2010). Conference of Parties to the STCW Convention 1978, Conference Resolution I, Regulation I/14/.7. London: IMO. International Maritime Organization (2012) International shipping facts and figures Information resources on trade, safety, and security, environment. Maritime Knowledge Center. Retrieved from http://www.imo.org/en/KnowledgeCentre/ShipsAndShippingFactsAndFigures/Th eRoleandImportanceofInternationalShipping/Documents/International\%20Shippi ng\%20-\%20Facts\%20and\%20Figures.pdf

International Maritime Organization, (2014). HTW 2/3/4 - Validation of model training courses: Model course - Maritime English. IMODOCS. Retrieved on 19 May 2016 from https://docs.imo.org

Jenkins, J. (1998). Which pronunciation norms and models for English as an International Language?. ELT Journal, 52(2), 119-126.

Jenkins, J. (2000). The Phonology of English as an international language. Oxford: Oxford University Press. 
Jenkins, J. (2004). Research in teaching pronunciation and intonation. Annual Review of Applied Linguistics (24), 109-125

Johnson, B. (1999). English in the Global Maritime Distress and Safety System. World Englishes, 18(2), 145.

Kataria, A. K. A. (2011). Maritime English and the VTS. In Proceedings of the $23^{\text {rd }}$ International Maritime English Conference, 25-32

Levis, J. M. (2005). Changing contexts and shifting paradigms in pronunciation teaching. TESOL Quarterly, 39(3), 369-377.

Marine Accident Investigation Branch Accident Investigation Report (MAIB) 2/2010, (2010). Grounding of container vessel Maersk Kendal. Retrieved from: https://www.gov.uk/maib-reports/grounding-of-container-vessel-maersk-kendalon-monggok-sebarok-reef-in-the-singapore-strait

Matsuura, H., Chiba, R., \& Ara, S. (2012). International Intelligibility of Learner English. 商学論集, 81(2), 63-74.

Miller, G. A. (1956). The magical number seven, plus or minus two: some limits on our capacity for processing information. Psychological review, 63(2), 81.

Munro, M. J., \& Derwing, T. M. (1995). Processing time, accent, and comprehensibility in the perception of native and foreign-accented speech. Language and speech, 38(3), 289-306. 
Munro, M. J., \& Derwing, T. M. (1999). Foreign accent, comprehensibility, and intelligibility in the speech of second language learners. Language learning, 49(1), 285-310.

Munro, M. J. (2008). Foreign accent and speech intelligibility. Phonology and Second Language Acquisition, 36,193-218.

Munro, M. J., \& Derwing, T. M. (2011). The foundations of accent and intelligibility in pronunciation research. Language Teaching, 44(03), 316-327.

Munro, M. J., \& Derwing, T. M. (2015). A prospectus for pronunciation research in the 21st century: A point of view. Journal of Second Language Pronunciation, 1(1), $11-42$.

Nelson, C. L. (2008). Intelligibility since 1969. World Englishes, 27(3-4), 297-308.

Pickering, L. (2006). Current research on intelligibility in English as a lingua franca. Annual Review of Applied Linguistics, (26), 219-233.

Sampson, H., \& Zhao, M. (2003). Multilingual crews: communication and the operation of ships. World Englishes, 22(1), 31-43.

Smith, L. E., \& Nelson, C. L. (1985). International intelligibility of English: Directions and resources. World Englishes, 4(3), 333-342.

Smith, L. E. (1987). Language spread and issues of intelligibility. Georgetown University Round Table on Languages and Linguistics, 250-64.

Smith, L. E., \& Nelson, C. L. (2008). World Englishes and issues of intelligibility. In The Handbook of World Englishes 428-445. Blackwell Publishing Ltd : Oxford, UK. 
Smith, L. E., \& Rafiqzad, K. (1979). English for cross-cultural communication: The question of intelligibility. TESOL Quarterly, 371-380.

Snow, M. A., \& Brinton, D. M. (1988). Content-based language instruction: Investigating the effectiveness of the adjunct model. TESOL Quarterly, (22)4, (Dec., 1988), 553-574.

Takagi, N., \& Stone, L. (2010). World Maritime English Accents. Retrieved from: http://www2.kaiyodai.ac.jp/ takagi/pweb/wme.htm

Tang, L., Llangco, M., \& Zhao, Z. (2015). Transformations and continuities of issues related to Chinese participation in the global seafarers' labour market. Maritime Policy \& Management, 1-12.

Tauroza, S., \& Luk, J. (1997). Accent and second language listening comprehension. RELC Journal, 28(1), 54-71.

Trenkner, P., (2005). The IMO - Standard marine communication phrases - Refreshing memories to refresh motivation. In Proceedings of the $17^{\text {th }}$ International Maritime English Conference, 3-16.

Trenkner, P., \& Cole, C. (2010). Raising the Maritime English bar: The STCW Manila Amendments and their impact on Maritime English. In Proceedings of the 22nd International Maritime English Conference, 3-16.

Uchida, Y., \& Takagi, N., (2012). What did you say? Why communication failures occur on the radio. In International Maritime Lecturers' Association (IMLA) Proceedings of the IMEC 24. 170-179 
Zampini, M. (2008). L2 speech production research. Phonology and Second Language Acquisition, 36, 219-243.

Zhang, L. (2013, May). International Intelligibility of Chinese-Accented English. In Proceedings of The Fifth International Conference of English as a Lingua Franca 327-334.

Ziarati, R., Ziarati, M., \& Çalbaş, B. (2009). Improving safety at sea and ports by developing standards for maritime English. In Bridge conference, Finland.

Zielinski, B. W. (2008). The listener: No longer the silent partner in reduced intelligibility. System, 36(1), 69-84. 


\section{Appendices}

\section{Appendix A: Ship Position Titles and Duties}

The list below offers the reader a general description of the various ship positions and

duties of mariners. This list is not exhaustive of all positions on a merchant ship nor all the duties of each position; however it includes the positions held by the participants in my study and a general overview of their respective duties. (Source: CSL (Canada Steamship Lines) Group (https://www.cslships.com/en/careers/working-csl/ship-based; accessed, 18 April 2016)

Master - The Master is the official representative of the company and acts as the manager of the vessel. The Master must also comply with all the pertinent regulations regarding the operation of the ship. In addition to these duties, the Master must ensure the safety of the ship, crew, cargo and the environment.

\section{Deck Department:}

Officers of the Watch - The Officers of the Watch are the highest ranking crew within the Deck Department. They all possess the certifications needed to occupy these positions and are also known as 'licensed crew'.

Chief Officer (C/O) (also known as First Officer/Chief Mate/First Mate) The Chief Mate is the second in command. As such, the Chief Mate is responsible for all deck operations and for applying the company's procedures and regulations to both the equipment and the crew. The Chief Mate is also responsible for a Watch. 
Second Officer $(2 / \mathrm{O})$ - (also known as Second Mate). The Second Mate is the ship's navigator and is responsible for maintaining efficient navigation equipment. The Second Mate needs to update all the charts and publications and prepare the ship's passage plans. The Second Mate is also responsible for a Watch.

Third Officer (3/O) - (also known as Third Mate). The Third Mate is the most junior officer in the Deck Department and accomplishes tasks as instructed by the Master and the Chief Mate. The Third Mate is also responsible for a Watch.

Deck Cadet (D/C) - a graduate of a maritime academy or vocational school who spends a period of time on board learning before taking on the duties of a third officer.

Ratings - Ratings, otherwise known as 'unlicensed crew', are not necessarily unlicensed. Though some positions require a specialized certificate, these crew members have not gone through officer training.

Able-Bodied Seaman (ABS)/ Certified Rating, (also known by the initials “AB”) The Able-Bodied Seaman takes on this position after having passed the Bridge Watch Rating (BWR) certificate. The Able-Bodied Seaman acts as the helmsman or the lookout and, during the unloading of the vessels, performs deck duties under the orders of the Officer of the Watch. The Able-Bodied Seaman also serves as a Watchkeeper.

The Ordinary Seaman (O/S)/ Uncertified Rating (also known by the initials “OS”) occupies the most junior position on the ship. The O/S works under the supervision of the Officer of the Watch and acts according to the Officer's instructions.

\section{Engine Department:}


Officers - The Officers of the Engineering Department are the highest ranking crew within the Department. They all possess the certifications needed to occupy these positions and are also known as 'licensed crew'.

Chief Engineer $(\mathrm{C} / \mathrm{E})$ - The Chief Engineer $(\mathrm{C} / \mathrm{E})$ is the official representative of the Engineering Department and acts as its manager. The Chief Engineer is responsible for all the equipment on board, as well as the safety of the crew and environment within the department's purview.

Second Engineer (2/E) The Second Engineer reports to the Chief Engineer and is responsible for the everyday operation of the engine room. The Second Engineer acts as instructed by the Chief Engineer.

Third Engineer (3/E) The Third Engineer is an Officer of the Watch and is responsible for the maintenance of the engine room equipment as instructed by the Second Engineer.

Fourth Engineer (4/E) The Fourth Engineer is the most junior officer in the Engineering Department. The Fourth Engineer has similar duties to the Third Engineer, particularly as they are both responsible for the engine room Watches. 


\section{Appendix B: Maritime English Corpus Phrases}

The following sets of sentences comprise the Maritime English Corpus messages, (Takagi \& Stone, 2010). To create my stimuli, I used portions of these sentences with various speakers. The messages recorded are as follows:

1. My flag state is X. My last port of call was $\mathrm{Y}$. My cargo is crude oil. (X is the speaker's home country, $\mathrm{Y}$ is the nearest port.)

2. Aft station, aft station, this is bridge. Make fast the tug on the starboard quarter.

3. The pilot boat is approaching. Rig the pilot ladder 1 meter above water.

4. My present course is 135 degrees. My speed is 15 knots.

5. The CPA of the vessel 30 degrees on our port bow is 3 nautical miles, the TCPA is 13 minutes.

6. We will use the starboard anchor and put 7 shackles in the water.

7. Mayday, Mayday, Mayday. This is motor vessel $\mathrm{X}$, spelling. ( $\mathrm{X}$ is the speaker's mother's name (i.e. MAMA), and the phonetic spelling Mike Alpha Mike Alpha, etc. follows.) Our present position is 090 (zero nine zero) degrees from the Bravo Buoy, distance 5 cables. I am on fire after explosion. I am sinking. 
THESIS: MARITIME ENGLISH INTELLIGIBILTY STUDY

\title{
Appendix C: Language Background Questionnaire
}

\author{
Language Background Questionnaire \\ 语言背景调查问卷
}

Please answer the following questions:

请回答如下的问题 :

Age 年龄

Nationality 国籍

First language 母语:

Pŭtōnghuà (Mandarin) 普通话

Yuè (Cantonese) 禀语

Mĭn Nán (Southern Min) 闽南话

Jìnyŭ 晋语 / 山西话

Hakka 客家话

Xiāng (Hunanese) 湘语 / 湖南话

Gàn 赣语 / 江西话

Mín Běi (Northern Min) 闽北话

Mín Dōng (Eastern Min) 闽东话

Mín Zhōng (Central Min) 闽中话

Pŭ-Xián 莗仙话

Huīzhōu 徽州话

Other languages known 其他语言

First language/dialect of mother 母亲的母语/方言

First language/dialect of father 父亲的母语 /方言 
Where do you live now? 现在在哪里居住?

(City 市, Province 省)

Where did you live when you were a child? 儿时在哪里居住?

(City 市, Province 省)

How often do you speak English? (circle one) 讲英语的频率 (圈出一个)

Never 从不 / 2-3x year 每年 / 2-3 次 / 2-3x month 每个月 / 2-3 次 / weekly 每周 / daily 每天

In general, how well do you communicate in English? (circle one) 整体英语沟通能力（ 圈出一个)

$\begin{array}{lllll}1 & 2 & 3 & 4 & 5\end{array}$

None 没有 / A little bit 有一点 Some 有一些 Quite well 還不错 Very well 非常好

Please rate your ability in English using the following scale (circle one)

你的英语能力 (圈出一个)

- speaking 口语

Very poor 非常差 Poor 差 Fair 還可以 Functional 比较好 Good 好

Very good 非常好 Native-like 母语水平

- listening 听力

Very poor 非常差 Poor 差 Fair 還可以 Functional 比较好 Good 好

Very good 非常好 Native-like 母语水平 


\section{- writing 写作}

Very poor 非常差 Poor 差 Fair 還可以 Functional 比较好 Good 好

Very good 非常好 Native-like 母语水平

\section{- reading 阅读}

Very poor 非常差 Poor 差 Fair 還可以 Functional 比较好 Good 好

Very good 非常好 Native-like 母语水平

\section{- grammar 语法}

Very poor 非常差 Poor 差 Fair 還可以 Functional 比较好 Good 好

Very good 非常好 Native-like 母语水平

How long have you studied English?

英语学习年限__years 年—_months 月

Where did you study English? 在哪里学的英语?

(circle one - you many circle more than one if applicable)

( 圈出一个 - 如果必要, 可以多选)

grade school 小学、初中 high school 高中 vocational school 职业技术学校 university 大学 Masters Degree 硕士 Ph.D. 博士

What is your highest education level? (circle one) 最高学历（圈出一个）

grade school 小学、初中 high school 高中 vocational school 职业技术学校 university 大学 Masters Degree 硕士 Ph.D. 博士 
Your current job 目前的工作:

Current position (job) on ship 船上的具体岗位

How many years have you worked in the shipping industry?

在行业内工作的时间___ years 年

To which countries do your normally sail 经常航海去哪些国家

Have you worked with mixed nationality crews? (circle one) 有与多国船员工作的经历吗？（圈出一个） Yes 是 No 否

If yes, please list the nationalities of crewmembers with which you have worked 如 果有与多国船员工作的经历，请列出这些船员的国籍 
When do you use English (speak/listen) for your job? (Please circle any of the following that apply.) 您在工作中什么时候讲 / 听英语 ? ( 请圈出所有适合您的选项 )

\begin{tabular}{|c|c|c|c|c|}
\hline Context 场合 & Situation 情形 & & & \\
\hline $\begin{array}{l}\text { Navigating } \\
\text { 航海 }\end{array}$ & $\begin{array}{l}\text { VHF radio 高频 } \\
\text { 航海对讲 }\end{array}$ & $\begin{array}{l}\text { VTS personnel } \\
\text { 船舶交通管理系 } \\
\text { 统人员 }\end{array}$ & Pilots 引航员 & $\begin{array}{l}\text { Tug } \\
\text { operators 拽 } \\
\text { 曳操作员 }\end{array}$ \\
\hline $\begin{array}{l}\text { Shore-based } \\
\text { personnel 地 } \\
\text { 勤 }\end{array}$ & $\begin{array}{l}\text { Ship's Agent 传播 } \\
\text { 运输代理人 }\end{array}$ & Customs 海关 & $\begin{array}{l}\text { Immigration } \\
\text { 移民局检查 } \\
\text { 站 }\end{array}$ & $\begin{array}{l}\text { Port State } \\
\text { Control } \\
\text { Officers 港口 } \\
\text { 控制官员 }\end{array}$ \\
\hline $\begin{array}{l}\text { On board } \\
\text { Ship 船上 }\end{array}$ & $\begin{array}{l}\text { Give orders 发出 } \\
\text { 命令 }\end{array}$ & $\begin{array}{l}\text { Receive orders } \\
\text { 接收命令 }\end{array}$ & $\begin{array}{l}\text { Talk to other } \\
\text { crewmembers } \\
\text { (social } \\
\text { interaction)与 } \\
\text { 其他船员沟 } \\
\text { 通 ( 社交活 } \\
\text { 动) }\end{array}$ & \\
\hline $\begin{array}{l}\text { Other } \\
\text { interaction } \\
\text { 其他 }\end{array}$ & $\begin{array}{l}\text { Talk to manning } \\
\text { agency 与海员外 } \\
\text { 派公司沟通 }\end{array}$ & & & \\
\hline
\end{tabular}

Please write any other times that you use English 请列出其他使用英语的场合

Thank you for participating in this survey 感谢您参与本研究. 


\section{Appendix D: Instructions for Listening Test/Verbatim Response}

In this section of the survey, you will listen to eight phrases 接下来您会听到 8 句话. Each phrase will be spoken in English by a different person 每句话都是一个不同的人用英语讲的.

You will hear different accents of English 您会听到不同口音的英文.

You will hear the phrase only one time 每句话您只能听一遍.

After you hear the phrase, please repeat in English exactly what you heard. You will be recorded 每听一句话, 请重复。会有录音.

For example, you may hear the phrase: My cargo is crude oil. 比如：您可能听到：

After you hear the phrase, you will repeat: “My cargo is crude oil." 听到这句话后, 您 只需原样重复说：

Do you have any questions about the test and what you are to do? 您有什么问题吗?

I will now play a sample phrase for you. We will adjust the sound as needed.

现在我给您放一个样本。我们可以调节音量。

This phrase will be similar to ones you may here.

这个样本和您即将听到的 8 个句子很相似。

Please repeat in English exactly what you heard. 请按照原句重复。

Again, you will only hear the phrase one time. 再次提醒您，每个句子只能听到一。 Please repeat in English exactly what you heard. 请按照原句重复。

Please let me know when you are ready. 准备好开始的话, 请您告诉我。 (begin test)

检测开始 


\section{Appendix E: Instructions for Participant Impressions of Speaker}

The following are instructions for the second portion on the study which gathered information related to the listeners' impression of the speaker including the overall intelligibility and comprehensibility of the speaker. These instructions were read to each participant, and a copy in English and Chinese was given to the participant to follow along. Participants were able to ask any questions after I read the instructions. I wrote down their answers to the questions.

In this section of the survey, please tell me what you thought of each speaker after you listen to the phrase again.

请您告诉我您听第二遍时对每个说话者的看法

You can listen to the phrase again as many times as you like. 您可以不断反复听这个句子。

After you hear the phrase, I will ask you the questions on this paper. Please tell me your answers to the questions out loud in English.

您听过这个句子后，我会问您这张纸上的问题。请口头回答这些问题。

You do not need to write anything. You will be recorded.

您不需要写字。但是会被录音。

Do you have any questions about the instructions? 您有任何问题吗? 
Test 检测

Speaker 讲话者

If you were on a ship, what would you do or say in reply if you heard this phrase?

如果您在船上, 听到这句话后您会说或者做什么?

Rate your overall impression of the speaker: (select a number) 您对讲话人的整体印象（选择一个数字）

1

I did not know any of the words

一点也没有听懂
2

3

I knew some of the words

听懂了一些单词
4 5

I knew all of the words 听懂了全部单词

Which of the following statements is most true for you?

如下哪个陈述最接近您的看法?

1

His accent was very difficult for me to understand 他的口音很难懂
2

3

His accent was moderately difficult to understand 他的口音有一点难懂
4 5

His accent was easy to understand 他的口音很容易懂

What made the accent easy or difficult to understand?

是什么使得这种口音容易或难以理解?

What word(s) were difficult to understand? 哪些词比较难? 
What made the words difficult to understand, for example:

什么使得这些词这么难理，比如

He spoke fast. 他语速太快

I did not know the meaning of the word. 我不知道那个单词的意思

He did not pronounce the word clearly. 他的发音不准

I did not know the meaning of the phrase. 没有听懂句子的意思

What language does this speaker speak as a first (native) language?

这个讲话者的母语是什么?

Have you heard this accent before? 您有听过这种方言吗？Yes or No 是或否

If yes, how often have do you speak with someone with this accent? 如果听过这种方言，您与讲这种方言的人沟通的频率

$$
\text { Once 2-3x year 2-3x month weekly daily }
$$

一次 一年 2-3 次 每月 2-3 次 每周 每天

Is there anything else you would like to tell me about this speaker? 有关这个讲话者您还有什么要补充的信息吗? 


\title{
Appendix F: Consent Form
}

The Portland State University Consent to Participate in Research

\section{Maritime Intelligibility Study}

\author{
Version January 2016 \\ 波特兰州立大学 \\ 参与研究同意书 \\ 海事语言可懂度研究 \\ 版本：2016 年 1 月
}

Introduction 概况

You are being asked to participate in a research study that is conducted by Dr. Tucker Childs, Principal Investigator, and Christine Holland, from the Department of Applied Linguistics, at Portland State University in Portland, Oregon. This research is studying the intelligibility of accented English to Chinese Mariners.

您被邀请参与一项研究。该研究主要目的是研究带口音英文的可懂度，研究对象是 中国海事人员，主要研究者为美国俄勒冈州波特兰州立大学应用语言学系 Tucker Childs 博士和 Christine Holland。

You are being asked to participate in this study because you are a mariner from China. You have a unique job that exposes you to many varieties of English and your input is very important.

您被邀请参与该研究，主要是因为您作为中国海事人员的特殊身份。您的独特工作 使您有机会接触各种口音的英文，对这些带口音英文的理解对您的工作至关重要。 
This form will explain the research study, and will also explain the possible risks as well as the possible benefits to you. We encourage you to talk with your family and friends before you decide to take part in this research study. If you have any questions, please ask one of the study investigators.

该同意书会向您简要介绍该研究及参与该研究可能给您带来的风险与利益。我们建 议您在决定参与该研究前事先与家人和朋友沟通。如果您有任何问题，请随时联系 两位研究者中的任何一位。

What will happen if I decide to participate? 决定参与该研究所涉及的工作

If you agree to participate, the following things will happen:

如果您决定参与该研究，您需要做如下几件事情:

1. You will fill out a questionnaire that asks questions about your language background and you job. 您需要填写一份有关您的语言及工作背景的调查问 卷。

2. You will listen to phrases spoken in English and you will repeat exactly what you heard in English. 您需要听一些用英语讲的带口音的句子，并在听后做逐字 重复。

3. You will be asked questions about your impressions of the speaker and what you understood. 您需要回答一些有关您对讲话者的印象和对讲话者所说内容理解 度的问题。

How long will I be in this study? 参与时间

Participation in this study will take a total of 45-50 minutes. 参与这项研究需要占据您 45-50 分钟的时间。

What are the risks or side effects of being in this study? 参与该研究可能的风险有哪 些?

There are risks of stress, emotional distress, inconvenience and possible loss of privacy and confidentiality associated with participating in a research study. 参与该项目可能会 给您带来压力，情绪低落，麻烦及泄漏隐私。 
However we believe there is minimal risk to you for participating in this study. We will make the process for participating in this study as efficient as possible as we know your time is valuable. We are taking several measures to securely store the data in order to safeguard your privacy and confidentiality. 但是我们相信，参与该研究给您带来的可 能风险是极小的。因为我们知道您的时间非常宝贵，所以我们会争取以最高的效率 完成整个过程。我们会采取各种措施安全存储您的资料以确保您的隐私得到最大限 度的保护。

For more information about risks and discomforts, feel free to ask the investigator. 如果 您还有任何其他问题，请随时咨询研究人员。

What are the benefits to being in this study? 参与该项目的利益有哪些?

There will be no direct benefit to you for participating in this study. However, your responses are very important and may lead to collaborative work to improve English language classes for mariners around the world. Your input will be useful to determine how pronunciation differences among speakers affects the ability of the listener to understand the speaker. 参与该项目不会给您带来任何直接利益。但是，您的参与非 常重要，因为您的参与可能会带来深远影响，比如国际合作进行全球范围内海事人 员英文培训。您的参与会有助于我们确定讲话者不同的英文口音对听话者理解的影 响。

How will my information be kept confidential?

我的信息会受到什么样的保护?

We will take measures to protect the security of all your personal information, but we cannot guarantee confidentiality of all study data. Confidentiality of all data will be maintained by keeping the data on a computer that is password protected in a folder that is also password protected. Your responses will not be directly associated with your name. 我们会采取各种措施保护您的个人信息安全，但是我们很难确保所有研究 资料的保密性。我们对研究资料采取的主要保密措施是将资料保存在设有密码的电 脑中设有密码的文件夹里。您的回答不会直接与您的名字关联。

Information contained in your study records is used by study staff. The Portland State University Institutional Review Board (IRB) that oversees human subject research and/or other entities may be permitted to access your records, and there may be times when we are required by law to share your information. It is the investigator's legal obligation to 
report child abuse, child neglect, elder abuse, harm to self or others or any lifethreatening situation to the appropriate authorities, and; therefore, your confidentiality will not be maintained. 您的资料只有该项目的研究人员可以读取和使用。波特兰州 立大学伦理委员会监督该项研究。其他机构可能被运行获取您的研究资料。有时法 律可能会要求您分享信息。研究人员有法律责任向相关权威机构汇报任何形式的虐 待儿童、虐待老人、对他人造成伤害及威胁生命安全的行为。在这些情况下，您的 隐私将不会得到保护。

Your name will not be used in any published reports about this study. 您的名字不会出 现在有关这项研究的任何出版材料中。

Will I be paid for taking part in this study? 参与该研究是否有薪酬?

You will not be paid for this study, however your participation is very much appreciated. 参与该项研究是没有薪酬的，但是我们非常感谢您的参与。

Can I stop being in the study once I begin? 可以中途停止参与吗?

Your participation in this study is completely voluntary. You have the right to choose not to participate or to withdraw your participation at any point in this study without penalty or loss of benefits to which you are otherwise entitled. 您的参与完全是靠自愿。您有权 在任何时候退出，退出时没有任何惩罚或利益损失。

Whom can I call with questions or complaints about this study? 如果我有不满可以找什 么机构进行投诉?

If you have any questions, concerns or complaints at any time about the research study, Dr. Tucker Childs or Christine Holland will be glad to answer them at 015033389204 or 01503725 2040. 如果您有任何不满意，可以打电话给 Tucker Childs 博士或 Christine Holland，电话号码：01503 3389204 或 01503725 2040。

If you need to contact someone after business hours or on weekends, please call 01503 3389204 and ask for Christine Holland, lillian3@pdx.edu. 如果您想在非工作时间或周 末联系研究人员，请拨打 015033389204 ，找 Christine Holland 女士。 
Whom can I call with questions about my rights as a research participant? 如果我想咨询 研究参与者权利方面的信息，应该问谁?

If you have questions regarding your rights as a research participant, you may call the PSU Office for Research Integrity at (503) 725-2227 or 1(877) 480-4400. The ORI is the office that supports the PSU Institutional Review Board (IRB). The IRB is a group of people from PSU and the community who provide independent oversight of safety and ethical issues related to research involving human participants. For more information, you may also access the IRB website at https://sites.google.com/a/pdx.edu/research/integrity. 如果您向咨询参与者权利方面的 信息，请致电波特兰州立大学研究诚信办公室的电话：(503) 725-2227 或 1(877) 480-4400。研究诚信办公室为波特兰州立大学伦理委员会提供支持。伦理委员会有 波特兰州立大学的成员组成，提供涉及人类参与者的科学研究的安全及伦理问题监 督服务。如果您想获取这方面更多的相关信息，请访问研究有关研究诚信的网站： https://sites.google.com/a/pdx.edu/research/integrity。

\section{CONSENT 同意书}

You are making a decision whether to participate in this study. Your signature below indicates that you have read the information provided (or the information was read to you). By signing this consent form, you are not waiving any of your legal rights as a research participant. 您正在做有关是否参与该研究的决定。您的签名将表明您已经 仔细阅读过此前的信息。签名不意味着您放弃任何作为研究参与者的权利。

You have had an opportunity to ask questions and all questions have been answered to your satisfaction. By signing this consent form, you agree to participate in this study. A copy of this consent form will be provided to you. 您有机会提问并获得满意的答复。 通过在同意书上签名，您同意参与该研究。您会得到一份该同意书的副本。

Name of Adult Subject (print) 姓名 Signature of Adult Subject 签字 Date 日期 


\section{INVESTIGATOR SIGNATURE 研究人员签名}

This research study has been explained to the participant and all of his/her questions have been answered. The participant understands the information described in this consent form and freely consents to participate. 研究人员已向参与者解释了该研究，参与者的 所有相关问题都已得到满意的答复。参与者完全理解该同意书中的相关信息并自愿 同意参与该研究。

Name of Investigator/ Research Team Member (type or print) 研究人员姓名

(Signature of Investigator/ Research Team Member)研究人员签字

Date 日期 


\section{Appendix G: Participant Attitudes towards Nationality/L1 of Speakers}

The following questions were asked after all eight phrases were re-listened to.

Please tell me what you think about the English accents of people from:

您认为是什么口音

Japan 日本

Russia 俄罗斯

China 中国

United States 每国

Canada 加拿大

Is there anything else that you would like to tell me regarding listening to people with other accents of English? 针对英语的口音, 您还有什么想法要与我分享吗? 


\section{Appendix H: Areas of Reduced Intelligibility as Perceived by Participants}

\section{Sentence 1: My last port of call was St. Petersburg.}

The most problematic area of the sentence was the place name. Only one of nine participants who listened to the Russian speaker say this phrase was able to parse [sent 'piz.b.g] as "St. Petersburg.

\section{Sentence 2: Make fast the tug on the starboard quarter.}

The collocation "make fast" was difficult. Regardless of speaker, for the participants who did not understand the phrase, the collocation "make fast" was interpreted as "make first", "make stand" or the word "fast" was deleted. Without understanding the first part of the phrase, the remaining portion of the phrase was unintelligible.

\section{Sentence 3: Rig the pilot ladder one meter above water.}

The beginning of the phrase "Rig the pilot ladder" proved unintelligible to most (24/39) of the participants. The imperative "rig" was deleted or replaced in some instances with "put", "please prepare", "make”, and "play”.

\section{Sentence 4: My present course is one three five degrees.}

The numbers of degrees in Sentence 4 caused difficulties. Participants were able to recall "My present course is", but said a variety of responses for the numbers "one, three, five degrees". These responses included deleting a number, inserting an extra word, switching the order of the numbers, or not being able to recall any numbers. 


\section{Sentence 5: We will use the starboard anchor.}

This phrase, while short with only 6 words and 7 syllables, had two areas of reduced intelligibility. Participants had difficulty with the beginning of the sentence "We will use" and heard this in two instances as an imperative "Use the starboard anchor", or as a question, "Will we use", reversing the order of words. Additionally, when the Russian speaker said "starboard anchor", the /d/ in starboard was devoiced and the /t/ assimilated to <anchor> creating the word "tank" or "tanker" to be heard.

\section{Sentence 6: The pilot boat is approaching.}

The was the most intelligible sentence regardless of speaker. Thirty-three of 39 participants found this phrase to be fully intelligible with a rating of 5. It is likely that the phrase was highly intelligible due to the fact that it was the shortest sentence (5 words), and had the least amount of syllables (6 syllables).

\section{Sentence 7: Put seven shackles in the water.}

The phrase "seven shackles" caused difficulty with participants substituting "some shackles" or "something" for "seven shackles".

\section{Sentence 8: The TCPA is thirteen minutes.}

The acronym "TCPA" said by the Japanese speaker was problematic. Eight of the nine participants who heard the Japanese speaker understood "two ships" as part of the pronunciation for "TCPA". Additionally, thirteen (13) was repeated as thirty (30). 